\title{
Parental Leave Legislation and Women's Work: A Story of Unequal Opportunities
}

\author{
Sari Pekkala Kerr* \\ Wellesley College
}

June 11, 2013

U.S. federal and state family leave legislation requires employers to provide job protected parental leave for new mothers covered under the legislation. In most cases the leave is unpaid, and rarely longer than 12 weeks in duration. This study evaluates disparities in parental leave eligibility, access and usage across the family income distribution in the United States. It also describes the links between leave taking and women's labor markeet careers. The focus is especially on low-income families, as their leave coverage and ability to afford taking unpaid leave is particularly poor. This study shows that the introduction of both state and federal legislation increased overall leave coverage, leave provision and leave taking. The new policies did not, however, reduce gaps between low- and high-income families' eligibility, leave taking or leave length. In addition, the FMLA effects on leave taking were not stronger in states without prior leave legislation, nor for women who met the eligibility criteria, as these women were already relatively well covered by other parental leave arrangements. The increased leave taking does not have significant effects on womens' wages, earnings, employment or promotions. The small career effects may partly be due to the very limited leave length in the United States.

JEL: I3, J13, J18, J21, J31, M51

Keywords: Family leave legislation, parental leave, eligibility, low-income families, career, NLSY, CPS

${ }^{*}$ Corresponding author. Contact address: Wellesley Centers for Women, Wellesley College, 106 Central Street, Wellesley MA 02481. Email: skerr3@wellesley.edu. This work has been funded by the 35th Anniversary Fund of Wellesley Centers for Women. I am grateful to Meaghan Maher and Meredith Stoner for excellent research assistance. 


\section{INTRODUCTION}

The United States is one of the few developed countries that does not have a universal parental leave legislation covering all employees. Furthermore, even those employees that are covered by the existing legislation are typically not guaranteed paid leave, or a leave exceeding 12 weeks. The generosity of parental leave policies depends on the state of residence, tenure and work hours with the employer as well as the size of the employer firm. Covered employees are guaranteed 12 weeks of unpaid leave under the federal Family and Medical Leave Act (FMLA). Paid family leave mandates are currently limited to California and New Jersey which recently passed the Paid Family Leave Insurance program. ${ }^{1}$ Some states have specific mandates above and beyond the coverage of the FMLA, extending coverage to smaller firms or employees with a shorter tenure.

This study evaluates disparities in parental leave eligibility, access and usage across the family income distribution in the United States. In addition, it describes the effects of the leave policies on women's usage of parental leave, and its connection to their labor market careers with a particular emphasis on low-income women. Parental leave is often applauded for its beneficial effects on the wellbeing of both the child and the mother. ${ }^{2}$ It is also argued that mandated parental leave improves women's economic position by allowing them to retain their former employment during and after pregnancy. While previous research has evaluated the effects of parental leave on female labor market participation and employment, few studies have conducted careful empirical evaluations on leave usage and the effects accruing to economically disadvantaged populations. Indeed, both recent academic research and popular press articles, such as Anne-Marie Slater's highly debated 2012 account in the Atlantic, have focused on highly educated career women while ignoring the realities facing the majority of working mothers. ${ }^{3}$

Better career progress, greater earnings and job retention are related to human capital and labor market experience. Women's labor market histories, however, display gaps in participation during years of family building: women are more likely than men to interrupt their work careers for family

1. The FMLA passed in 1993 covers full-time workers working at least for one year in companies with more than 50 employees. California PFL (commencing in 2004) provides 6 weeks of partially paid leave to the participants of the State Disability Insurance. New Jersey PFL (commencing in 2008) similarly provides 6 weeks of partially paid leave to employees working for firms that are subject to the NJ Unemployment Compensation Law.

2. While outside of the scope of the current study, several previous studies have evaluated the effects of parental leave on child outcomes. See for example Berger et al., 2005; Chatterji et al., 2011; Gregg and Waldfogel, 2005; Ruhm, 2005; Tanaka, 2005; and so on.

3. See e.g. Anne-Marie Slater "Why women still can’t have it all", the Atlantic July/August 2012. 
reasons. These gaps reduce the amount of labor market experience women can accrue relative to men, a factor contributing to the gender wage gap. ${ }^{4}$ With mandated, job-protected parental leave employers are obligated to re-employ the new mothers to their earlier positions, and hence the existence of leave mandates might be beneficial to women's work careers. In that case, women would not lose their jobs, but instead be re-employed at their previous wage level and previous position in the career-ladder, meaning that they could retain the benefit from their tenure with the same employer. Low-income women may be more adversely affected by child bearing, depending on their eligibility to job protected parental leave and their ability to afford taking them.

This paper will specifically focus on economically disadvantaged employees with low family income. This group is the least likely to be covered by the parental leave legislation and also most vulnerable in terms of their job security. The aim is to test whether the leave eligibility, probability of taking any family leave, and the length of leave taken is systematically related to the economic status of the new mothers. Also, this study will take a look at these women's labor market careers. In particular, the economic outcomes of interest include a) women's return to employment postbirth, b) risk of unemployment, c) short- and long term growth in hourly wages and earnings, and d) incidence of promotions. Together these economic outcomes offer an extensive view of the women's labor market careers in the United States.

The analysis of NLSY and CPS data finds that there are indeed sizeable differences in the incidence and length of parental leaves across the family income distribution that are at least partly related to the legal eligibility and employer provision of leaves. In addition, while the state and federal policies have affected leave taking on average, they have not done anything to reduce the disparities across family income quartiles. Due to the FMLA criteria related to job tenure and firm size, it does not provide very good coverage for women in low-income families. Instead, it focuses coverage to women in steady jobs that likely already provide parental leave arrangements through company policies. Finally, the additional leave taking induced by the FMLA does not appear to be adversely related to women's career outcomes, at least at the currently mandated length.

The rest of this paper is structured as follows. Section II provides some background on the

4. There is a vast literature on gender wage gap, an issue that remains beyond the scope of the current study. Some of the most relevant studies include Arulampalam et al., 2007; Blau and Kahn, 1992, 1994 and 2003; Waldfogel, 1998b. 
economic issues related to parental leave and describes the relevant empirical literature. Section III presents the state and federal family leave policies, and the data used in the analysis. Section IV outlines the empirical framework and discusses the validity of the research design. Section V presents the empirical findings, and Section VI concludes with an international comparison.

\section{Related Academic Literature on Parental Leave}

To date, there is scant evidence on parental leave coverage and usage in relation to family economic status: Few studies have evaluated the feasibility and effects of family leave for lowincome families. One related study looked at the expansion of Canadian paid family leave and found that most of the leave benefits accrued to women in relatively advantaged population groups rather than disadvantaged families (Hanratty and Trzcinski, 2009). ${ }^{5}$ The most directly related analysis comes from a master's thesis by Conover (2007), who uses data from the 2006 March Current Population Survey (CPS) to test whether women with higher income levels are more likely to take parental leave under the FMLA than women with lower income levels. She finds that income indeed positively affects the probability of leave taking, and suggests that paid leave policies are required to promote leave-taking along the whole income distribution. Klerman and Leibowitz (1994) also show that access to paid leave is positively related to "market skills" such as schooling and work experience. Survey evidence supports the notion that many women who would have liked to take a parental leave (or a longer leave) were unable to afford it (e.g. A Workable Balance: Report to Congress on Family and Medical Leave Policies, 1996, cited in Waldfogel, 2001).

In addition, a few studies report statistics on the access to paid or unpaid family leave by income level. Recent BLS reports show that low earners are only half as likely to have access to paid family leave relative to the average private sector employee (5\% and $11 \%$, respectively). ${ }^{6}$ According to those reports access to unpaid leave is currently available to $85 \%$ of all workers, yet for only $77 \%$ of the lowest $25 \%$ of earners. Comparing the recent BLS reports to more historical publications also gives an interesting insight into the evolution of parental leave coverage in the U.S.. While

5. They did not find any effects on returns to employment or relative employment.

6. BLS (2011) National Compensation Survey: Employee Benefits in the United States, March 2011. ClemensCope et al. (2008) show that low-income families are also much less likely to have access to paid sick leave to take care of their children, and consequently less likely to use sick leave for family needs. 
access to paid leave is still very far from universal, the overall family leave situation has certainly improved in the last 20 years: in 1992 only $2 \%$ of workers had paid leave available, and unpaid leave was available for $15 \%$ of employees in small firms and $37 \%$ in medium and large firms. ${ }^{7}$

Previous research has demonstrated that interruptions in women's employment hinder their career progress, and parental leave in particular has negative effects on earnings that may last longer than those associated with other types of leave. ${ }^{8}$ In contrast, other studies argue any negative effects of family leave disappear after returning to work, and those taking parental leave eventually catch up with employees who did not take leave. ${ }^{9}$ In countries without universal parental leave coverage, such as the U.S., women are also often hesitant to take leave due to the perceived negative consequences. ${ }^{10}$

Earlier research on the U.S. Family and Medical Leave (FMLA) has largely concentrated on its effects on female labor supply, instead of addressing the wider question of female labor market careers. ${ }^{11}$ Waldfogel (1999a and 199b) finds that the FMLA increased leave coverage and encouraged leave taking, but she did not observe any significant effects on wages and employment. Conversely, Baum (2003) studied the FMLA as well as state level parental leave policies, and argued that family leave legislation did not affect leave taking, although it did increase women's return to employment after child birth. ${ }^{12}$ Berger and Waldfogel (2004) agreed that those women with parental leave coverage were more likely to return to employment after 12 weeks. In fact, a third of the US women return to work within 3 months of child birth, while over a half of women have returned within 6 months. ${ }^{13}$ In her dissertation Kane (1998) analyzed the pre-FMLA state policies, finding that they improved women's access to parental leave, increased female employment but reduced their

7. Bureau of Labor Statistics (1994) Employee Benefits in Small Private Establishments, 1992; BLS (1993) Employee Benefits in Small Private Establishments, 1991. See also Bureau of Labor Statistics (1998) Employee Benefits in Medium and Large Private Establishments, 1995; Bureau of Labor Statistics (1999) Employee Benefits in Small Private Establishments, 1996.

8. Joshi et al. (1996), Buligescku et al. (2008), Manchester et al. (2010).

9. Waldfogel (1998).

10. Hochchild (1997), Crittenden (2001), Glass (2004), Bardasi and Gornick (2008).

11. Some studies have looked at the effects of parental leave on children and family well-being. As these issues are outside of the scope for the current study, that research is left out of this review.

12. Baum (2003) evaluated the effect of FMLA by comparing those who were legally eligible to those who were not eligible, according to the FMLA criteria. The legal eligibility is not, however, a good characterization for actual leave availability, as many who are not eligible nevertheless work for employers who offer paid or unpaid leave. For example, according to the NLSY data, after the FMLA $66 \%$ of legally non-eligible workers worked for an employer who offered paid leave to at least some of their workers.

13. The majority of mothers who work when their child is 12 months old have returned by 3 months (Klerman and Leibowitz, 1994). 
wages. $^{14} 15$

Finally, a recent study provides an interesting perspective on parental leave and the careers of high-powered women. Bertrand et al. (2010) studied MBAs who graduated from top U.S. business schools in 1990-2006, and found that the male-female pay gap grows rapidly soon after the MBAs start their careers. Much of this increase can be attributed to career interruptions and shorter working hours of the women, mostly related to the presence of children. The authors have also examined the "Harvard \& Beyond"-alumni project and found similar, if somewhat smaller, child related career costs for female MDs, JDs and PhDs. The career costs of child birth are therefore not limited to women working in low-skilled occupations and those with lower earnings, but are apparent even for women with the highest educational qualifications.

\section{Description of the Policies, Research Design, and Data}

The United States is one of the few countries that does not mandate a paid parental leave that would cover all employees. Figure 1 shows a comparison of parental leave mandates by type and length across a selection of developed countries. The Family and Medical Leave (FMLA) legislation enacted in 1993 created for the first time a national mandate for medium-size and large companies to offer family leave for those new parents covered under the legislation. The history of parental leave legislation in the United States is discussed below.

14. In Sweden, Albrecht et al. (1999) find that family related career interruptions do not harm womens' wage growth, whereas they do reduce wages for men. Ronsen and Sunstrom (1996) compare family policies in Sweden and Norway, and find that access to paid parental leave speeds up women's return to work. Ruhm (1999) notes that rights to job-protected parental leave increase women's labor market participation and employment in Europe, but long mandated leave duration increases the gender pay gap. Zweglich et al. (2003) show that maternity benefits increased womens' labor inputs in Taiwan. Waldfogel (1995) finds that UK legislation extending rights to job protected leave reduced the pay gap between working mothers and other women. Baker and Milligan (2008) find that, in Canada, leave mandates of up to 18 weeks do not affect women't probability of returning to employment, while longer leaves reduce returning to work.

15. Very little research exists on the relationship between taking parental leave and the incidence of promotions. Studies evaluating promotion differences by gender include e.g. Groot et al (1996, and Blau and DeVaro (2006). Winter-Ebmer and Zweimuller (1997) evaluate gender differences in promotion rates in the context of women's higher likelihood of quitting their job entirely, and find that expected fertility and past career interruptions negatively affect women's progress on the career ladder in Austria. 


\section{III.A. State Reforms}

State parental leave reforms have taken place over the last 40 years, beginning in Massachusetts where the legislation was established in 1972. The Massachusetts legislation required private firms with at least 6 employees to offer 8 weeks of unpaid family leave for employees who had at least 3 months of tenure. By 1993 altogether 13 states and the District of Columbia had passed some form of parental leave legislation. The timing of the state reforms and the rules for coverage are shown in table 1. It should be noted that even after 1993 some states have a more extensive leave coverage than required by the FMLA, for example extending the coverage to smaller firms or for employees who have a shorter tenure or fewer work hours than necessary for the FMLA coverage. In addition, a few states (RI, CA and DC) have mandated a leave length longer than 12 weeks. The state policies have changed over time, and the data collected for this study follows these changes from year to year. The sources for the state policy changes are reported in a separate list of references.

According to my calculations based on the National Longitudinal Study of Youth (NLSY), the state mandates made roughly $35 \%$ of women working in the private sector in the covered states legally eligible for parental leave. The eligibility varies across the income distribution, reaching up to $41 \%$ for those in the highest $25 \%$ of the family income distribution, and falling as low as $25 \%$ for the bottom 25\%. ${ }^{16}$ Similar calculations were made using the Current Population Survey (CPS), and the estimates match the patterns found in the NLSY. According to the January CPS, approximately $42 \%$ of women working in the private sector in the covered states would have been made legally eligible for parental leave as a result of the state policy reforms. The share ranges from $34 \%$ to $45 \%$ by quartile of the family income distribution. ${ }^{17}$

\section{III.B. The FMLA}

The FMLA guarantees 12 weeks of job protected parental leave for those employees who meet the eligibility criteria. Legally eligible employees are those who work for private companies that have at least 50 employees, and have worked for the company at least 12 months for a total of

16. This calculation includes years 1991-92 for the states that implemented a policy prior to 1993. All women aged 26-35 working for private companies are included, whether they had children or not. Of men, 42 percent would have been legally eligible for parental leave based on the state policy criteria in 1991-92.

17. Data on job tenure are available only in scattered CPS supplements prior to 1996. This calculation uses the 1991 January supplement. All women aged 20-40 working for private companies are included, whether they had children or not. 
1,250 hours per year. Public sector employees are covered by the FMLA regardless of employer size. Importantly, the FMLA does not guarantee paid leave, the provision of which is left at the discretion of the employer.

While the FMLA created a uniform policy framework across all states, the coverage it created is far from universal. Based on the Bureau of Labor Statistics publications on Employee Benefits in Medium and Large Establishments, and Employee Benefits in Small Private Industry Establishment, the passage of the FMLA significantly increased the parental leave availability in the U.S. Prior to the FMLA, under 40 percent of full time employees in medium and large establishments (i.e. establishments with more than 100 employees) were offered either paid or unpaid parental leave, while only 20 percent of employees in small establishments (less than 100 employees) were offered such leave. After the FMLA was passed in 1993, the share of full time employees with family leave availability in large and medium enterprises increased to 95 percent, while it remained somewhat lower, at 50 percent, in the small establishments. Most of the covered employees were offered an unpaid leave of exactly 12 weeks. I am not aware of any studies conducted around the FMLA introduction (or later) that would dissect parental leave availability by family income.

In the nationally representative NLSY data, the FMLA marginally increased the share of legally eligible women to $40 \%$ in those states that already had previous parental leave mandates and made $38 \%$ of female employees eligible in states that did not have a prior mandate. Again, eligibility varies greatly across the family income distribution. Those in the lowest $25 \%$ are much less likely to be covered $(26 \%)$ than those in the top $25 \%(45 \%) .{ }^{18}$ Actual leave availability can of course be greater than this, as it partly depends on employer policies (as shown by the BLS numbers above). It should be noted that calculating actual leave availability (i.e. whether the employer offers job protected parental leave to a specific person) is complicated in the NLSY as it only asks whether paid parental leave is provided by the employer. A more detailed analysis of the leave availability and incidence is presented in section 5. A similar calculation was made using the Current Population Survey (CPS), where data on job tenure and other FMLA criteria are collected in the January supplement biannually after 1996. The post-FMLA eligibility estimates fall relatively close to those found for the NLSY: $45 \%$ of female employees were made eligible in

18. This calculation includes years 1994-98. All women aged 29-41 working for private companies are included, whether they had children or not. For men, the FMLA similarly made about 39 percent legally eligible for parental leave in 1994-98. 
states that did not have a prior mandate, and $46 \%$ in those states that already had a leave policy in place. These shares vary from $34 \%$ to $52 \%$ by the family income quartile. ${ }^{19}$

The implementation of the FMLA means that there are several groups of women who would potentially be most affected by the newly available parental leave, and whose leave taking would therefore be impacted by the reform. For example, women who fulfill the eligibility criteria could be expected to benefit most from the mandated leave, especially if they live in states that did not previously have any leave mandate in place. Alternatively, women whose employer did not previously offer any job protected family leave might be more likely to take advantage of the new arrangement allowed by the FMLA. Changes in leave taking around these and other likely margins are evaluated in section 5 below.

\section{III.C. Data Sets and Samples}

Table 2 summarizes the key demographic and work history variables, along with the employment and earnings outcomes for the NLSY1979 sample. ${ }^{20}$ The NLSY contains questions on a wide range of issues including: 1) employment, wages, promotions, and employer characteristics, 2) fertility, care giving, and families, and 3) fringe benefits such as employer provided parental leave. The sample used for the current analysis includes mothers who gave birth between 1985 and 1999, and were working in the private sector prior to giving birth. Mothers who worked for the military or were self-employed in the two years immediately prior to birth are excluded, as are those who had a non-interview at that time. Likewise employees of local, state or federal government are excluded from the final sample as they are subject to different parental leave policies. Multiple births are included per mother, as the unit of observation is a birth. After excluding observations that have missing values for key variables the total sample size is 2,493 births, and all respondents are followed until 2008. While the NLSY is a nationally representative sample, it oversamples Black, Hispanic and economically disadvantaged persons. Customized sample weights are used to adjust for this oversampling when calculating the descriptive statistics. ${ }^{21}$

19. This calculation includes years 1996 and 1998. All women aged 20-40 working for private companies are included, whether they had children or not.

20. The NLSY was initiated in 1979 with 12,686 respondents aged 14 to 22 . The follow-up interviews took place annually from 1979 through 1993, and then biennially from 1994 through 2008.

21. Alternative data sources include the CPS or the NICHD, of which neither is ideally suited for the current study. The CPS does not follow the same individuals from year to year, and does not have a firm size cut-off at 50 employees. 
For estimation purposes data are needed on births taking place before and after the policy changes. As state and federal parental leave mandates are separately evaluated, the states and time periods are grouped as follows. The states are classified into those with and without preFMLA parental leave mandates. For the states that had an earlier mandate (prior to 1993), the births are divided into those taking place prior the state mandate, those between the state mandate and the FMLA, and those taking place after the FMLA. For states without prior mandates, births are simply classified as taking place before or after the FMLA. Table 3 shows the sample sizes within these cells.

In 1985, the youngest mother in the data was 20 years old and the oldest was 28 . Even though the sample period covers the peak fertility years for most of these women, it cannot be claimed that the sample is representative of overall birth rates for that period. The data will also not capture all births for these mothers. In 1985, for example, 13 percent of all births were for mothers aged less than 20 and 6 percent for those aged 35 or more (NCHS data). ${ }^{22}$

In addition to the NLSY, comparisons are provided to the Current Population Survey (CPS) data whenever possible. CPS is a monthly survey of 60 to 80 thousand households conducted by the Bureau of Labor Statistics (BLS). It includes data on topics such as employment, hours of work and earnings, along with demographic and labor force characteristics for each household member. As shown above, a combination of March and January supplements to the CPS can be used to determine eligibility to parental leave under the state and/or the FMLA criteria. The January supplement contains the necessary information on job tenure and hours worked for 1987, 1991, and then biannually from 1996 onward, while the March supplement gives details on employer size. ${ }^{23}$ Likewise, the June supplement can be used to calculate the percentage of mothers with young children who are actually taking parental leave during the first 3 months after child birth. Each supplement includes a question on family income, allowing the calculation of these statistics across

The NICHD follows the new mothers for a few years, but does not reveal information about their employer size, job tenure or annual hours worked. It is also not a nationally representative sample.

22. In 1999, the corresponding percentages were $12 \%$ and $13 \%$. Sources: Documentation of the Detail Natality Tape File for 1999 Data, and Public Use Data Tape Documentation: 1985 Detail Natality. U.S. Department of Health and Human Services, National Center for Health Statistics. See also Livingston and Cohn (2010) for a recent discussion.

23. It should be note that the CPS is not ideally suited for this purpose as the employer size cut-off is not reported at 50 employees, the limit used by the FMLA and many state mandates. For that reason, the CPS estimates on leave eligibility should be considered approimations. CPS reports firm size limits at 25 and 100 employees. Since the distribution of U.S. establishment sizes is fairly linear between 25 and 100 employees (e.g. Henly and Sanchez, 2009), point estimates for eligibility can be based on the percentile points between the upper and lower bounds created by the CPS firm size limits. See table 4c for more details. 
the family income distribution. However, as the CPS does not follow the same individuals over a longer period of time it cannot be used to evaluate the effect of leave taking on career metrics.

\section{IDENTIFICATION AND Estimation}

The goal of this paper is to evaluate differences in parental leave availability, actual leave taking and the effects of leave taking across the family income distribution. Of particular interest are the low-income families and their access to leave as well as their ability to take any parental leave to which they are legally entitled. The U.S. data also in principle enable the identification of any career effects of parental leave due to changes and variations in the family leave policies over time and across states and firms. These variations would create discontinuities in the eligibility of women who give birth at different points in time, in different locations and who work for firms of different sizes. Assuming that suitable data exists, these discontinuities suggest that an evaluation of the career effects might be possible.

The first part of the estimation framework ic concened with the effect of family leave policies on leave taking. ${ }^{24}$ In case of the pre-FMLA state policies, the first stage would take the following form.

(1) $L_{i}=\alpha+\gamma^{\prime} D_{s(i)}+\theta^{\prime} D_{t(i)}+\beta P_{s(i) t(i)}+\delta^{\prime} X_{i}+\epsilon_{i}$,

where $L_{i}$ is an indicator that mother $i$ takes parental leave after giving birth or a measure of the total leave length taken. $D_{s}$ are the state specific dummies and $D_{t}$ the year-of-birth (of the child) dummies. $P_{s(i) t(i)}$ is an indicator taking value one if the birth took place in a state that implemented a pre-FMLA parental leave policy after the time when the policy was implemented. $X_{i}$ is a vector of other person specific covariates, including e.g. race, marital status, number of children, education, earnings prior to leave, and age groups.

As the interest here is on the distributional effects of the parental leave policies, measures of family income are introduced in the estimated equations. Here, family income $\left(I_{i}\right)$ is included in the leave equation along with its second and third polynomial, and as an interaction with the post-reform dummy For the case of the FMLA, the estimated equation takes the form.

24. In a causal model of the effects of parental leave taking on women's career indicators this would also represent the first stage of the model. 
(2) $L_{i}=\alpha+\gamma^{\prime} D_{s(i)}+\theta^{\prime} D_{t(i)}+\beta P_{t(i)}+I_{i}+I_{i}^{2}+I_{i}^{3}+I_{i} \times P_{t(i)}+\delta^{\prime} X_{i}+\epsilon_{i},: i$.

Finally, if it is found that the FMLA and/or state policies have an impact on leave taking, a second stage equation can be estimated for the various career metrics such as employment. Depending on the type of natural experiment that can be conducted on the available data, these equations could be estimated as a reduced form, differences-in-differences or with instrumental variables. The identifying assumption is that the family leave reforms do not affect family formation decisions systematically differently by "career mindedness" or some other unobserved factor that influences the career metrics. This assumption can be studied indirectly by looking at the effects of the reforms on overall fertility across states. Cannonier (2011) argues that the FMLA did increase the overall fertility, but did not show significant differences e.g. across income groups. ${ }^{25}$

\section{Main Results: The Effect of Parental Leave Policy REFORMS}

\section{V.A. Impact of reforms on leave provision, eligibility and leave taking}

As already discussed above, women with low family income are much less likely to be legally covered by the family leave mandates created through the FMLA and state reforms. Tables 4a and $4 \mathrm{~b}$ summarize by family income quartile whether the new mothers were legally entitled to job-protected parental leave. Legal entitlement is here defined as having an employer immediately prior to the child birth with at least the minimum number of employees for whom the new mother had worked at least the minimum duration and minimum number of annual hours required by the (state or federal) mandate. In the case of the FMLA, this would mean having worked for at least 12 months and 1250 hours per year for an employer who had at least 50 employees.

Under the pre-FMLA state policy mandates (table 4a), only 27 percent of women in lowest family income quartile qualified for job protected parental leave, whereas more than half of the women in the top two quartiles were legally entitled to leave. According to the FMLA criteria, 32 percent of the women in the lowest income quartile were legally eligible for parental leave, while as at least 50 percent of women in the highest quartiles met the eligibility criteria. The tables

25. Research in other countries confirms that family policies affect fertility rates, without really changing the relationship between fertility and economic status (e.g. Bjorklund, 2006; Lalive and Zweimuller, 2009). 
also dissect the reasons for ineligibility by individual criteria and all their combinations. For most women who were not legally covered by the state mandates or the FMLA, the firm size requirement appears to be a factor. Those at the bottom of the income distribution were also more frequently made ineligible due to a short job tenure, and to some extent fewer hours worked.

An analysis of the CPS January and March supplements reveals a similar pattern across the family income distribution (table 4c). Only 36 percent of women in the lowest family income quartile were legaly eligible for parental leave, while the share was much higher (55\%) in the top income quartile. Firm size is again a significant factor for most women, although the CPS sample also reveals large discrepancies across family income distribution in meeting the job tenure criteria. ${ }^{26}$

It should be noted that employers may provide job-protected (and even paid) parental leave for women who are not legally eligible for it, and smaller employees not covered by the policy requirements also frequently provide some leave arrangements for at least some of their employees. Tables 5a and 5b summarize by family income quartile the actual employer paid leave provisions and actual leave taking before and after the policy reforms. Prior to the state policy reforms, just over half of the employees in the lower family income quartiles worked for firms that provided paid parental leaves, whereas nearly three quarters of the employees in the top income quartile had paid leave available. It is notable that even those employees whose employers provide some paid leave arrangement do not necessarily take paid leave. This may be due to an insufficient compensation level during leave or the fact that paid leaves are not provided for all employees within the firm. For example, only 19 percent of the employees in the bottom income quartile report having used paid parental leave, even though 54 percent worked for an employer who had a paid leave policy available. The usage of paid leaves was much higher in the top income quartile (43 percent), although still much lower than the percentage of those whose employer supposedly provided a paid leave. The average leave length also varied considerably across income quartiles prior to the state policy implementation.

Provision of paid leaves increased in all family income groups after the state reforms, but the

26. One difference between the NLSY and CPS samples is the higher proportion of women with long job tenure in the NLSY. This is caused by the sampling of NLSY women who were employed prior to giving birth, which automatically emphasizes women with greater labor market attachment. While the NLSY sample can be thought of a representation of women with significant ties to the labor market, the CPS is more representative of all working women at a given point in time. The comparison of these two data sets is therefore instructive in giving a fuller picture of parental leave eligibility in the US. 
gap between the lowest and highest income quartile did not markedly change as a result (table 5a). The differences across income quartile remained particularly stark in the smaller firms. ${ }^{27}$ Likewise, leave taking and average leave length increased in all income groups, but much more so for the high income families such that the gaps between the lowest and highest quartile actually increased noticeably. Finally, after the state policy reforms the share of those women who took paid leave (as a percentage of employees whose employer provides paid leave) was much higher in the highest family income quartile and increased more than that in the lowest quartile relative to the pre-reform situation.

For the FMLA, paid leave provision increased most in the top family income quartiles, but the differences between the lowest and highest quartile remained largely unchanged (table 5b). Interestingly, leave taking and average length increased most in the third income quartile, but significant increases in leave taking also took place in the lower quartiles. Despite this, sizeable gaps in leave taking and length remain across the family income groups. Indeed, these numbers based on tables 5 and 4 describe a very unequal pattern of leave eligibility, provision and taking across the family income distribution. After the FMLA, just over a third of the lowest income quartile employees working in large firms with a paid leave policy actually took paid parental leave, while 67 percent of the highest income quartile employees did so. This may be related to the fact that even though the companies have paid leave available, employees in the lowest income quartile are not eligible to use it.

A similar analysis using the June CPS supplement shows very comparable patterns across the family income distribution. Mothers who gave birth in the previous 3 months were more likely to be employed and on parental leave after the FMLA than during the years prior to the FMLA. The analysis looks at women aged 20-40 who worked in a private sector firm at some point over the last 12 months prior to the June CPS interview. Overall, about 85 percent of them were employed at the time of the June interview prior to the FMLA, and this share increased to 89 percent after the FMLA. ${ }^{28}$ Of these same women, 39 percent were on parental leave at the time of the June interview prior to the FMLA. After the FMLA, just over 50 percent of the women were on parental

27. This increase may partly be related to the actual reforms, but there has also been a general trend of increased leave provision that needs to be accounted for in the regression analysis.

28. Years 1990 and 1992 are used as the pre-FMLA period, whereas the post-FMLA period consists of 1994,1995 and 1998. 
leave in June; a sizeable increase over a period of a few years. Table 5c shows an analysis of these patterns across the family income distribution. Just as was shown for the NLSY, there are very large differences in leave taking across quartiles of the family income distribution. Women in lowincome families are much less likely to return to employment after giving birth, and also much less likely to be on parental leave at the time of the CPS interview. The differences in leave taking are not reduced after the FMLA, but appear larger in the post-FMLA period, if anything.

A simple regression model for the probability of meeting the FMLA or state eligibility criteria shows that women with higher family incomes are much more likely to meet the criteria both during the entire time period as well as in the post-reform period (Table 6, columns 1 and 4). ${ }^{29}$ When estimating the model using the continuous definition of family income (column 2) the effects at various points of the family income distribution are calculated at the bottom of the table. These calculations again show that women at the higher end of the income distribution are much more likely to meet the eligibility criteria. Likewise, a simple regression for the probability of taking any leave implies that women with a higher family income are more likely to take leave (column 3 ). Based on the information shown here and in tables $4 \mathrm{a}$ and $4 \mathrm{~b}$ it would appear that the greater leave taking is likely associated with working in a job that allows the woman to meet the eligibility criteria (long tenure, full time work, large employer). In most cases the direction of the estimates is similar in the post-reform period (column 4). However, during the post-reform period the model with the continuous definition of family income shows estimated effects that are somewhat nonlinear at the top of the distribution and therefore a third polynomial is added to better capture the shape of the family income effect. ${ }^{30}$. Overall, it seems that the effect of family income on the probability of meeting the eligibility criteria is, if anything, greater in the post-reform period. The next set of tables turns to a more detailed analysis of leave taking in relation to family income and the policy reforms.

When estimating the effect of the FMLA, and controlling for state fixed effects, time trends and individual characteristics, the NLSY data reveal an increased probability of leave taking by nearly 20 percentage points, and increased average leave length by 5 weeks across all states after

29. In this regression, a person is considered to meet the FMLA criteria if they worked for the same employer for at least 52 weeks, 1250 hours per year and their employer had at least 50 employees. This is a technical definition applied to both the pre- and post-FMLA births, and therefore does not capture the actual eligibility.

30. A model without the additional third polynomial for family income produces essentially flat and statistically insignificant estimates for the post-reform period. 
the reform (Table 7, columns 1 to 3 ). No significant increase is seen for paid parental leaves, as might have been expected since the FMLA did not stipulate anything about pay during leave. The FMLA effects are very similar in those states that did not have a previous mandate, although the effect remains statistically significantly only for leave length (columns 4 to 6). As shown in the previous tables, leave taking varies noticeably across the family income distribution, and clear patterns emerge where women with higher family incomes are more likely to take leave and stay on leave longer. The FMLA does not appear to have impacted the differences across family income groups, as shown by the small and statistically insignificant interaction term. Finally, the state policy reforms do not show any statistically significant effects on any of the leave metrics studied here, although a distinct pattern by family income is clearly noticeable (columns 7 to 9 ).

In order to evaluate whether the FMLA affected parental leave taking in those groups that one might most likely expect, Table 8 breaks down the FMLA estimates across different subpopulations. First, it might be expected that the FMLA had its greatest impact in states that did not have a prior parental leave mandate, if it made a whole new population of women eligible for leave. As could be expected based on results shown above, this does not seem to be the case for any of the leave metrics. ${ }^{31}$ Similarly, it would be reasonable to assume that the FMLA mostly affected those women who met the eligibility criteria. In reality, it is true that women who meet the eligibility criteria are more likely to take paid and unpaid parental leave, and to take longer leaves, but the FMLA is not the reason behind the observed pattern. Instead, these women are more likely to work in jobs where the employer offered a more generous leave arrangement already before the FMLA, and are therefore more likely to take leave. Third, it could be expected that women working in medium-sized firm (instead of large or small firms) would be most affected by the FMLA. Waldfogel (1999) found some evidence for that pattern using the CPS. The NLSY data give some indication that leave taking increased most for women working in medium-sized firms, but the effects are not statistically significant. Interestingly, women working in large firms are most likely to take both paid and unpaid leave, and have longer leave durations. This again signals that those firms offer the most generous leave arrangements, regardless of the FMLA. To conclude this analysis, the FMLA effects are evaluated for women whose family income was in the bottom tercile

31. Using CPS data Waldfogel (1999) also found that the FMLA actually had its largest effects in states with prior lwas on leave taking. 
of the distribution. Again, it appears that those women are less likely to take any kind of leave in general. There is some indication that the FMLA increased unpaid leave taking for that group, but the effect is only weakly significant. The breakdown of FMLA effects across the most likely groups to be affected shows that the groups most targeted by the FMLA probably already enjoyed a reasonably high parental leave coverage and were not particularly strongly affected by the new law.

\section{V.B. Connection to career metrics}

This section describes the connection of parental leave taking and leave length to the various career metrics first for the full NLSY sample used in this study and then separately for the low family income group, i.e. families whose income falls below the median of the sample. Some of the estimates in Table 7 revealed a reasonably strong first stage for the FMLA that could possibly be exploited in a 2SLS or differences-in-differences estimation. It should be noted, however, that the FMLA does not satisfy the requirements for an "ideal natural experiment" that could be conducted: there is no evidence that leave taking increased more for those who became legally eligible for leave as a result of the FMLA. ${ }^{32}$ Hence, the most reasonable way to utilize the FMLA policy change is to create a comparison of women giving birth before and after the FMLA, interacting the pre and post dummies with an indicator of leave taking. This is a much weaker test, and therefore the NLSY sample size may not be large enough to detect statistically significant effects connected to the FMLA induced changes in leave taking.

The career metrics are calculated at 1,2,3 and 4 years after the birth of the child related to the parental leave in order to capture both the short-run and long-run effects of leave taking. The metrics are defined as follows. First, the mother is considered employed if she reported a positive number of hours worked for the relevant calendar year, and unemployed if she reported some (or all) weeks looking for work since the last relevant interview. Second, annual earnings are deflated using the CPI series published by the BLS (all urban consumers series), and then a natural logarithm

32. The most likely reason for this is that those who were legally eligible for leave after the FMLA already had a high prevalence of employer provided paid parental leave prior to the FMLA, and hence their situation was not much improved by the new legislation. In addition, the FMLA appears to have more widely increased leave provision, possibly due to employer awareness of the importance of such a benefit, or increased competition among employers for female employees. Baum (2006) shows that for the full NLSY sample (including those women not giving birth as well as males), family leave legislation significantly increased employer leave provision and did so in particular for eligible employees working in covered (i.e. larger) firms. 
is taken. The earnings regressions only consider persons that had some positive earnings during the relevant interview year, and combine all earnings across jobs if the person had more than one job during the year. Third, hourly wages are also in logarithms and deflated using the CPI, and likewise only considered for those who reported positive hourly wages during the relevant interview year. If the person had multiple jobs during the year, the hourly wage from their first reported employer was used. Finally, during some interviews NLSY participants are asked whether their job position had changed relative to the previous year, and whether this change was related to a promotion or demotion. ${ }^{33}$ A linear probability model is estimated for the likelihood of being promoted since the previous year.

The OLS estimates in Table 8a show a positive and statistically significant connection of taking any parental leave after child birth with the probability of employment, annual earnings, hourly wages and the probability of promotion. For example, those mothers taking any leave were 26 percent more likely to be employed and working one year after birth and 9 percent less likely to be unemployed. They had considerably higher earnings (46\%) and hourly wages (14\%), and were also more likely to receive a promotion in the year following birth (10\%). Similarly, a longer parental leave appears to be positively associated with greater post-birth employment, earnings and hourly wages. For example, taking an additional week of parental leave is associated with a 1.2 percent greater employment probability and 1.5 percent greater annual earnings. These positive associations do weaken, or even completely disappear, over time as shown by the declining estimates by year $4 .{ }^{34}$

The positive employment, earnings and promotion associations also exist for the low family income sample (table 8b), and no noticeable differences in the magnitudes of the coefficients exist to the full sample (table 8a). Likewise, the probability of unemployment is negatively related to taking any leave and total leave length both for the full sample and the low-income sample. And similar to the full NLSY sample, the observed associations between leave taking and career metrics weaken after a few years also for the low-income sample. As emphasized above, these estimated effects from the OLS regressions are most likely driven by self-selection: mothers with higher earnings and greater career focus are more likely to afford taking parental leave and more

33. The years when promotion were captured include 1988-1990, 1996, 1998, 2000, 2002, 2004, 2006 and 2008.

34. The weakening of the positive association takes place for all other career metrics except the hourly wage. The relationship between hourly wage and parental leave remains practically flat for the entire 4 years following the leave 
likely to utilize it. One way to retrieve the causal effect of taking parental leave on career indicators would be to use the timing of the FMLA and the state reforms as an instrument for leave taking. However, a careful study of the populations most affected by the reforms shows that reforms are less than ideal as "natural experiments". For example, those who become technically eligible as a result of the new legislation do no increase their leave taking more than others. This is most likely due to their already existing leave allowances by their employers, and the fact that they were already at a high level of parental leave usage prior to the reform date.

One way to utilize the NLSY data is to look at women's career outcomes before and after the reforms, and compare those taking parental leave to those not taking leave across the two time periods. While the overall effect of leave taking is still endogenous and positive, the interaction of the leave indicators and post-policy indicators is arguably less so. This analysis finds very small changes in the career metrics around the reform date, indicating that either the additional leaves induced by the reforms had little effect on womens' careers, or there simply isn't enough data to uncover the effects. For all of the metrics there is some indication that the relationship between leave taking and career outcomes experiences some reversal around the FMLA, but the effects are almost never significant (Table 11a). Indeed, the full sample shows mostly statistically insignificant relationship between the FMLA induced additional leaves and the career metrics. For the lowincome families, the results are strikingly similar (Table 11b). Given the sample size of the NLSY and the limited variation in leave taking it is difficult to make any further progress on the career analysis.

\section{Discussion and Conclusions}

This paper utilized the state and federal family leave legislation to study parental leave coverage, leave taking and womens' careers. In particular, the differences in leave coverage and utilization across the income distribution are described and it is shown that low-income women are less likely to be eligible for legally mandated parental leave, less likely to have employer provided paid and less likely to utilize their leave even if they are eligible.

Few studies or popular press articles have focused on the issues that low-income and middleclass families face when trying to combine work and family responsibilities. As one exception, in 
a 2006 Harvard Magazine article Elizabeth Warren describes the worsening financial position of middle-class families and notes that two earners are typically needed just to survive. Similarly, Nancy Folbre wrote a recent blog about children growing up in poor families, in particular with single mothers. These accounts of the economic vulnerability of single mothers and middle-class families, along with the results presented above, suggest that several policy measures could be taken to improve the ability of low-income and middle-class families to reach the goal of raising children while remaining actively engaged in the labor force. First, paid, job protected parental leaves would likely improve the ability of women from all family income groups to retain their jobs while affording to take time off to care for the newborn. This would help low-income mothers to retain their former employment and the benefits that accrue from a longer tenure with the same employer, and avoid the need to resort to welfare support. ${ }^{35}$ Second, extending the FMLA coverage to smaller firms and employees with a shorter tenure would significantly increase the eligibility of low-income women to parental leave and reduce the eligibility gap across income groups. Finally, as the career consequences of taking a leave at the currently mandated length are likely very minimal, from that perspective there is no reason why the U.S. leave mandates could not be extended beyond 12 weeks as is the case in most other industrialized countries.

As an example on leave coverage, if the firm size requirement of the FMLA was dropped from 50 to 10 employees the legal eligibility of women in the lowest family income quartile would increase from $32 \%$ to $48 \%$. If, in addition, the tenure requirement was dropped from 12 to 6 months, legal eligibility would further increase to $52 \%$, and if the annual hours worked requirement was further reduced to 600 as many as $63 \%$ of women in the lowest quartile would become eligible. For the highest family income quartile, these changes would increase eligibility to $64 \%, 67 \%$ and $78 \%$, respectively. Changes in the eligibility criteria could therefore have a significant impact in reducing the disparities in leave availability across the income distribution. To gauge the effect of paid family leave, consider that about $67 \%$ of women whose employer provides paid leave actually take leave, but leave is taken by only $30 \%$ of those whose employer does not provide paid leave. These shares range from $62 \%$ to $67 \%$, and $27 \%$ to $36 \%$ by family income quartile. Based on these simple calculations, if all women were provided paid leave, the overall leave taking might increase

35. Han et al. (2011) confirm that state family related policies importantly affects the employment of new mothers, especially those in the lower end of the family income distribution (those with no education and single mothers). 
from $59 \%$ to $67 \%$, and the overall gap between the family income quartiles would decrease by 21 percentage points. ${ }^{36}$ While these examples are only indicative of what might happen as a result of policy changes, they suggest that the disparities across income groups could be significantly reduced by increasing eligibility and/or introducing a paid parental leave policy. The evidence from other countries corroborates this hypothesis, as there are very small differences in parental leave taking across income groups in countries such as France, Finland, Sweden. Moreover, the importance of paid leave is highlighted in a recent study by Lalive et al. (2011), who show that leave length is significantly affected by cash benefits (rather than employment protection), but the leaves induced by cash benefits do not adversely affect women's labor market outcomes. Lalive and Zweimuller (2009) find that job protection mainly benefits high wage (white-collar) women, while low-wage women respond more strongly to cash benefits.

One closely related issue pertains of course to the availability of affordable child care after the new mother returns to employment. Klerman and Leibowitz (1990) note that child care costs of infants can be prohibitively high for families with more than one child. They evaluate the effect of child care subsidies on new mothers' labor supply and find that tax care credits increased the probability of returning to work within 3 months, but not beyond that. ${ }^{37}$ Walker (1996) discusses the affordable child care from the particular perspective of low-income parents and argues that the child care financing requires a fundamental reform. The NLSY data used in the current study show that returning to employment after child birth is much less frequent for low-income mothers, and becomes less likely after the mother has more than one child. These constraints would not be solved by increasing parental leave availability and financing, but might need to be alleviated by more affordable infant care.

Finally, a key difference between the U.S. and most other developed countries relates to the public provision versus mandating of parental leave. While most other countries rely on publicly provided and financed parental leave, the FMLA mandates certain firms to provide family leave to employees who fulfill specific criteria. In terms of the equitableness of leave access, Summers

36. Previous reports and studies on the impact of paid family leave include Fass (2009), Houser (2012) and RossinSlater et al. (2011). Waldfogel (2009) constrasts the U.S. situation to other nations. Cantor et al. (2001) and Waldfogel (2001) report than more than half of the women on parental leave are concerned about financial constrains.

37. Baker et al. (2008) show that availability of heavily subsidized, high quality child care indeed increases the use of child care and maternal employment. They also argue that the increased use of child care leads to worse family well-being. 
(1989) reminds that, while perhaps more efficient to provide, these kinds of mandated, employer provided benefits are by nature less equitable than publicly provided, tax financed benefits. The obvious problem with mandated benefits is that they only help those who have a job, and in the case of the FMLA, those who have a job that meets the FMLA criteria for eligibility.

While the current study finds few negative career consequences from taking parental leave, it should be noted that these results cannot be extended beyond the current leave framework. In particular, the small effects found here may well be due to the very short duration of the typical family leave in the United States relative to other countries. In addition, the small sample size of the NLSY makes it difficult to uncover statistically significant effects and to build a more causal estimation framework. It would be useful to consider using other, larger data sources for the United States, and also creating comparative analyses to other countries where parental leave is more extensive in length. Finally, while this paper has focused on the effects of parental leave on working mothers, a more extensive study evaluating the effects on employers and other employees would be warranted to form a more balanced picture of the issue.

\section{REFERENCES}

Albrecht, James W., Per-Anders Edin, Marianne Sundström, and Susan V. Broman. 1999. Career Interruptions and Subsequent Earnings: A Reexamination Using Swedish Data. The Journal of Human Resources 34(2): 294-311.

Arulampalam, Wiji, Alison L. Booth and Mark L. Bryan. 2007. Is There a Glass Ceiling over Europe? Exploring the Gender Pay Gap across the Wage Distribution. Industrial and Labor Relations Review 60(2), 163-186.

Bardasi, Elena, and Janet C. Gornick. 2008. Working for Less? Women's Part-Time Wage Penalties across Countries. Feminist Economics 14(1): 37-72.

Baum, Charles L. 2003. The Effects of Maternity Leave Legislation on Mothers' Labor Supply after Childbirth.

Baum, Charles L. 2006. The effects of government-mandated family leave on employer family leave policies. Contemporary Economic Policy Publisher 24(3): 432-445.

Baker, Michael, Jonathan Gruber, and Kevin Milligan. 2008. Universal Child Care, Maternal Labor Supply, and Family Well-Being. Journal of Political Economy 116(4): 709-745.

Baker, Michael and Kevin Milligan. 2008. How Does Job-Protected Maternity Leave Affect Mothers' Employment? Journal of Labor Economics 22(4): 655-691.

Berger, Lawrence M., Jennifer Hill, and Jane Waldfogel. 2005. Maternity Leave, Early Maternal Employment, and Child Health and Development in the US. The Economic Journal, 115 (February): F29-F47. 
Berger, Lawrence M., and Jane Waldfogel. 2004. Maternity Leave and the Employment of New Mothers in the United States. Journal of Population Economics 17(2): 331-349.

Bertrand, Marianne, Claudia Goldin, and Lawrence F. Katz. 2010. Dynamics of the Gender Gap for Young Professionals in the Financial and Corporate Sector. American Economic Journal: Applied Economics, 2(3): 228-55.

Björklund, Anders. 2006. Does Family Policy Affect Fertility? Lessons from Sweden. Journal of Population Economics 19(1): 3-24.

Blau, Francine D., and Jed DeVaro. 2006. New Evidence on Gender Differences in Promotion Rates: An Empirical Analysis of a Sample New Hires. National Bureau of Economics Research, Working Paper No. 12321.

Blau, Francine D., and Lawrence M. Kahn. 1992. The Gender Earnings Gap: Learning from International Comparisons. American Economic Review 82(2), 533-538.

Blau, Francine D., and Lawrence M. Kahn. 1994. Rising Wage Inequality and the U.S. Gender Gap. The American Economic Review 84(2): 23-28.

Blau, Francine D., and Lawrence M. Kahn. 2003. Understanding International Differences in the Gender Pay Gap. Journal of Labor Economics 21(1): 106-144.

Booth, Alison L., Marco Francesconi, and Jeff Frank. 2001. A sticky floors model of promotion, pay, and gender. European Economic Review 47(2003): 295-322.

Buligescu, Bianca, Denis de Crombrugghey, Gulcin Mentesoglu, and Raymond Montizaanz. 2009. Panel estimates of the wage penalty for maternal leave. Oxford Economic Papers 61, i35-i55.

Cannonier, Colin D. 2011. Essays in health economics and public policy. Ph.D dissertation. Department of Economics, Louisiana State University and Agricultural Mechanical College.

Cantor, David, Jane Waldfogel, Jeffrey Kerwin, Mareena M. Wright, Kerry Levin, John Rauch, Tracey Hagerty, and Martha S. Kudela. 2001. Balancing the Needs of Families and Employers: Family and Medical Leave Surveys. Rockville, MD: Westat.

Chatterji, Pinka, Sara Markowitz, and Jeanne Brooks-Gunn. 2011. Early Maternal Employment and Family Wellbeing. National Bureau of Economic Research, Working Paper No. 17212.

Clemans-Cope, Lisa, Matthew S. Pantell, Cynthia D. Perry, Genevieve M. Kenney, and Jennifer E. Pelletier. 2008. Access to and Use of Paid Sick Leave Among Low-Income Families with Children. Pediatrics 122: e480-e486.

Conover, Abigail E. 2007. Assessing the relationship between income and maternal leave taking under the 1993 Family and Medical Leave Act. Master's Thesis. Georgetown Public Policy Institute, Georgetown University.

Crittenden, Ann. 2001. The Price of Motherhood: Why the most important job in the world is still the least valued. New York, NY: Metropolitan Books.

Garcia-Crespo, Dolores. 2001. Promotions in the Spanish labor market: differences by gender. Oxford Bulletin of Economics and Statistics 63(5): 599-615.

Fass, Sarah. 2009. Paid Leave in the States: A Critical Support for Low-wage Workers and Their Families. National Center for Children in Poverty. Columbia University.

Gregg, Paul, and Jane Waldfogel. 2005. Symposium on Parental Leave, Early Maternal Employment and Child Outcomes: Introduction. The Economic Journal 115(February): F1-F6.

Glass, Jennifer. 2004.Blessing or a Curse? Work and Occupations 31(3): 367-394.

Groot, Wim, and Henriette Maasen van den Brink. 1996. Glass ceilings or dead ends: Job promotion of men and women compared. Economic Letters 53: 221-226.

Han, Wen-Jui, Christopher Ruhm, Jane Waldfogel, and Elizabeth Washbrook. 2011. Public Policies and Women's Employment after Childbearing, and Child Well-Being. The B.E. Journal of Economic Analysis \& Policy 11(1), 1935-1682. 
Hanratty, Maria and Eileen Trzcinski. 2009. Who Benefits from Paid Family Leave? Impact of Expansions in Canadian Paid Family Leave on Maternal Employment and Transfer Income. Journal of Population Economics 22(3): 693-711.

Henly Samuel E., and Juan M. Sanchez. 2009. The U.S. Establixhment Size Distribution: Secular Changes and Sectoral Decomposition. Economic Quarterly 95: 419-459.

Herman, Alexis M., and Katharine G. Abraham. 1998. Employee Benefits in Medium and Large Private Establishments, 1995. Bureau of Labor Statistics Bulletin 2496.

Herman, Alexis M., and Katharine G. Abraham. 1999. Employee Benefits in Small Private Establishments, 1996. Bureau of Labor Statistics Bulletin 2507.

Hersch, Joni, and W. Kip Viscusi. 1996. Gender Differences in Promotions and Wages. Industrial Relations 35(4): 461-472.

Hochschild, Arlie R. 1997. The Time Bind: When Work Becomes Home and Home Becomes Work. New York, NY: Metropolitan Books.

Houser, Linda. 2012. Pay Matters: The Positive Impacts of Paid Family Leave for Families, Businesses, and the Public. Rutgers Center for Women and Work.

Joshi, Heather, Susan Macran, and Shirley Dex. 1996. Employment after Childbearing and Women's Subsequent Labour Force Participation: Evidence from the British 1958 Birth Cohort. Journal of Population Economics 9(3): 325-348.

Kane, Carol K. 1998. State Mandates for Maternity Leave: Impact on Wages, Employment, and Access to Leave. PhD dissertation. Department of Economics, Boston College.

Klerman, Jacob Alex, and Arleen Leibowitz. 1990. Child Care and Women's Return to Work after Childbirth. The American Economic Review 80(2): 284-288.

Klerman, Jacob A., and Arleen Leibowitz. 1994. The Work-Employment Distinction among New Mothers. The Journal of Human Resources 29(2): 277-303.

Lalive, Rafael, and Josef Zweimüller. 2009. How Does Parental Leave Affect Fertility and Return to Work? Evidence from Two Natural Experiments. The Quarterly Journal of Economics 124(3): 1363-1402.

Lalive, Rafael, Analía Schlosser, Andreas Steinhauer, and Josef Zweimüller. 2011. Parental Leave and Mothers' Careers: The Relative Importance of Job Protection and Cash Benefits. IZA Discussion Paper 5792.

Livingston, Gretchen, and D'Vera Cohn. 2010. The New Demography of American Motherhood. Pew Research Center: Social \& Demographic Trends Report.

Manchester, Colleen Flaherty, Lisa M. Leslie, and Tae-Youn Park. Screening for Commitment: The Effect of Maternity Leave Use on Wages.

Reich, Robert B. 1993. Employee Benefits in Medium and Large Private Establishments, 1991. Bureau of Labor Statistics Bulletin 2422.

Reich, Robert B., and Katharine B. Abraham. 1994. Employee Benefits in Small Private Establishments, 1992. Bureau of Labor Statistics Bulletin 2441.

Rönsen, Marit, and Marianne Sundström. 1996. Maternal Employment in Scandinavia: A Comparison of the After-Birth Employment Activity of Norwegian and Swedish Women. Journal of Population Economics 9(3): 267-285.

Rossin-Slater, Maya, Christopher J. Ruhm, and Jane Waldfogel. 2011. The Effects of California's Paid Family Leave Program on Mothers' Leave-Taking and Subsequent Labor Market Outcomes. NBER Working Paper No. 17715.

Ruhm, Christopher J. 1998. The Economic Consequences of Parental Leave Mandates: Lessons from Europe. The Quarterly Journal of Economics 113(1): 285-317.

Ruhm Christopher J. 2005. Parental leave and child health. Journal of Health Economics: 19, 931-960. 
Solis, Hilda L., and Keith Hall. 2011. National Compensation Survey: Employee Benefits in the United States, March 2011. Bureau of Labor Statistics Bulletin 2771.

Summers, Lawrence. 1989. Some simple economics of mandated benefits. American Economic Review 39(2): 177-183.

Tanaka, Sakiko. 2005. Parental Leave and Child Health Across OECD Countries. The Economic Journal 115 (February): F7-F28.

Waldfogel, Jane. 1995. The Price of Motherhood: Family Status and Women's Pay in Young British Cohort. Oxford Economic Papers 47(4): 584-610.41.

Waldfogel, Jane. 1998a. Understanding the "Family Gap" in Pay for Women with Children. The Journal of Economic Perspectives 12(1): 137-156.

Waldfogel, Jane. 1998b. The Family Gap for Young Women in the United States and Britain: Can Maternity Leave Make a Difference? Journal of Labor of Economics 16(3): 505-545.

Waldfogel, Jane. 1999a. Family leave coverage in the 1990s. Monthly Labor Review 122: 13-21.

Waldfogel, Jane. 1999b. The Impact of the Family and Medical Leave Act. Journal of Policy Analysis and Management 18(2): 281-302.

Waldfogel, Jane. 2001. Family and Medical Leave: Evidence from the 2000 Surveys. Monthly Labor Review (September): 17-23.

Waldfogel, Jane. 2009. The Role of Family Policies in Antipoverty Policy. Focus 20(2): 50-55.

Walker, James R. 1996. Funding Child Rearing: Child Allowance and Parental Leave. The Future of Children 6(2): 122-136.

Winter-Ebmer, Rudolf, and Josef Zweimüller. 1997. Unequal Assignment and Unequal Promotion in Job Ladders. Journal of Labor Economics 15(1): 43-71.

Zveglich, Joseph E., and Yana van der Meulen Rodgers. 2003. The Impact of Protective Measures for Female Workers Journal of Labor Economics 21(3): 533-555.

\section{General References}

\section{References for State Policy Reforms}

National Partnership for Women \& Families (2005) Expecting Better: A State-by-State Analysis of Parental Leave Programs.

Shimabukuro, Jon and Cassandra LaNel Foley (2008) State Family and Medical Leave Laws.

Strumberg, Robert, Janice Steinschneider and George Elser (1989) State Legislative Sourcebook on Family \& Medical Leave.

Stutts, John R. and Frank Heiland (2006) Diversity in U.S. Family and Medical Leave Policy: A Comparison of Federal and State Legislation between 1972 and 2005.

United States Department of Labor: Women's Bureau (1993) State Maternity/Family Leave Law. Women's Legal Defense Fund (1994) State Family Leave Laws and Regulations.

\section{State Specific References}

California: Cal. Gov't Code $\S 12945.2$

Connecticut: Conn. Gen. Stat. $\S \S 31-51 \mathrm{kk}$ and 31-51ll

District of Columbia: D.C. Code $\S \S 32-501$ and $32-502$

Hawaii: Haw. Rev. Stat. $\S 398-3$

Maine: Me. Rev. Stat. Ann. tit. 26, $\S \S 843$ and 844

Massachusetts: Mass. Ann. Laws ch. 149, § 105D

Minnesota: Minn. Stat. $\S \S 18.940$ and 181.941

New Jersey: N.J. Stat. Ann. $\S \S 34: 11 B-3$ and B-4

Oregon: Or. Rev. Stat. $\S \S \S \S 659$ A.153 and 659A.156 and 659A.159 and 6569A.162

Rhode Island: R.I. Gen. Laws $§ \S 28-48-1$ and 28-48-2

Tennessee: Tenn. Code Ann. § 4-21-408 
Vermont: Vt. Stat. Ann. tit. 21, $\S \S 471$ and 472

Washington: Wash. Rev. Code $\S \S \S 49.78 .020$ and 49.78.220 and 49.78.240

Wisconsin: Wis. Stat. $\S 103.10$ 
Table 1: Eligibility Criteria for State Parental Leave Policies Enacted Before and After the FMLA, with Corresponding NLSY Sample Sizes by State

\begin{tabular}{|c|c|c|c|c|c|c|c|c|}
\hline State & Date of Policy & Firm size & Tenure & Hours & $\begin{array}{l}\text { Leave } \\
\text { length }\end{array}$ & $\begin{array}{l}\text { Total } \\
\text { Births }\end{array}$ & $\begin{array}{l}\text { Before } \\
\text { Policy }\end{array}$ & $\begin{array}{l}\text { After } \\
\text { Policy }\end{array}$ \\
\hline & & \multicolumn{7}{|c|}{ I. Parental Leave Policies Enacted Prior to the FMLA } \\
\hline CA & January, 1992 & 50 & 12 & 1,250 & 12 & 441 & 298 & 143 \\
\hline CT & July, 1990 & 75 & 12 & 1,000 & 16 & 107 & 54 & 53 \\
\hline DC & April, 1991 & 50 & 12 & 1,000 & 16 & 14 & 10 & 4 \\
\hline LA & January, 1987 & 26 & any & any & 6 & 40 & 11 & 29 \\
\hline MA & October, 1972 & 6 & 3 & full & 8 & 52 & 0 & 52 \\
\hline ME & April, 1988 & 25 & 12 & any & 10 & 2 & 1 & 1 \\
\hline $\mathrm{MN}$ & August, 1987 & 21 & 12 & $50 \%$ & 6 & 64 & 24 & 40 \\
\hline NJ & April, 1990 & 75 & 12 & 1,000 & 12 & 114 & 47 & 67 \\
\hline OR & January, 1988 & 25 & 3 & any & 12 & 22 & 9 & 13 \\
\hline $\mathrm{RI}$ & July, 1987 & 50 & 12 & 1,560 & 13 & 2 & 0 & 2 \\
\hline TN & January, 1988 & 100 & 12 & full & 16 & 51 & 17 & 34 \\
\hline VT & July, 1992 & 10 & 12 & 1,560 & 12 & 3 & 3 & 0 \\
\hline WA & September, 1989 & 100 & 12 & 1,820 & 12 & 56 & 24 & 32 \\
\hline \multirow[t]{2}{*}{ WI } & April, 1988 & 50 & 12 & 1,000 & 6 & 137 & 41 & 96 \\
\hline & & \multicolumn{7}{|c|}{ II. Parental Leave Policies Enacted After the FMLA } \\
\hline ME & 1995 & 15 & 12 & any & 10 & 2 & 1 & 1 \\
\hline OR & 1995 & 25 & 6 & 600 & 12 & 15 & 6 & 9 \\
\hline
\end{tabular}

* Sources: See the List for Policy References at the end of the paper.

* Notes: The policies enacted after the FMLA include only those that have more generous provisions than required by the FMLA. 
Table 2: Descriptive Statistics for the NLSY Sample of Women Who Gave a Birth in 19851999

\begin{tabular}{lcccc}
\hline & & & & \\
Variable & Mean & Min & Max & St.D. \\
\hline Mothers age at birth & 26.30 & 21 & 42.00 & 3.76 \\
Number of births in 1985-1999 & 1.64 & 1 & 5.00 & 0.72 \\
Parental leave legislation & 0.38 & 0 & 1.00 & 0.49 \\
Eligible for parental leave at birth & 0.17 & 0 & 1.00 & 0.37 \\
Takes any parental leave & 0.53 & 0 & 1.00 & 0.49 \\
Length of parental leave taken & 5.35 & 0 & 39.71 & 7.26 \\
Employer offers paid leave & 0.69 & 0 & 1.00 & 0.46 \\
Education: College & 0.39 & 0 & 1.00 & 0.49 \\
Education: HS & 0.55 & 0 & 1.00 & 0.50 \\
Married & 0.85 & 0 & 1.00 & 0.36 \\
Spouse's education at least HS & 0.77 & 0 & 1.00 & 0.42 \\
Family income & 9.38 & 0 & 14.42 & 3.93 \\
Number of children aged 0-2 & 0.37 & 0 & 4.00 & 0.54 \\
Number of children aged 3-5 & 0.25 & 0 & 3.00 & 0.48 \\
Black & 0.06 & 0 & 1.00 & 0.24 \\
Hispanic & 0.11 & 0 & 1.00 & 0.31 \\
Mothers hourly wage before birth & 2.28 & -4.31 & 7.27 & 1.10 \\
Employed in the 12 months after birth & 0.78 & 0 & 1.00 & 0.41 \\
Earnings after birth & 10.78 & 6.02 & 12.51 & 0.90 \\
Hourly wage after birth & 2.62 & -4.33 & 4.42 & 0.60 \\
Ever promoted after birth & 0.15 & 0 & 1.00 & 0.35 \\
Tenure with employer & 190.83 & 1 & 938.00 & 182.23 \\
Hours worked previous year & 1723.25 & 12 & 8320.00 & 696.42 \\
Employer size $>$ 50 & 0.51 & 0 & 1.00 & 0.50 \\
Number of respondents & 1,831 & & & \\
Number of observations (births) & 2,493 & & & \\
\hline & & & & \\
\hline
\end{tabular}

* Sources: NLSY data on births between January 1, 1986 and and December 31, 1999.

* Notes: Includes births to mothers working for a private comoany prior to the birth. Excludes persons who had worked for the military or the government during the year prior to birth, were self-employed, or had missing information for any of the key variables. 
Table 3: NLSY Data in States that Adopted Parental Leave Policies Prior to the Introduction of the FMLA Versus Other States

\begin{tabular}{|c|c|c|c|c|}
\hline \multirow[b]{2}{*}{ Group of States } & \multirow[b]{2}{*}{$\begin{array}{l}\text { Total } \\
\text { Births }\end{array}$} & \multicolumn{3}{|c|}{ After State } \\
\hline & & $\begin{array}{c}\text { Before } \\
\text { State Policy } \\
\text { and FMLA }\end{array}$ & $\begin{array}{l}\text { Policy, } \\
\text { Before } \\
\text { FMLA }\end{array}$ & After FMLA \\
\hline \multicolumn{5}{|c|}{ States with Pre-FMLA Parental } \\
\hline Leave Policies & 772 & 319 & 243 & 210 \\
\hline \multicolumn{5}{|l|}{ States without Pre-FMLA } \\
\hline Parental Leave Policies & 1,721 & 1,308 & $\mathrm{n} / \mathrm{a}$ & 413 \\
\hline All States & 2,493 & 1,627 & 243 & 623 \\
\hline
\end{tabular}

* Notes: See table 2. Excludes observations with missing values on key variables. Includes births taking place in 1986-1999. 
Table 4a: Eligibility for Parental Leaves under the State Parental Leave Policy (pre-FMLA) and Criteria for Eligibility by Family Income Quartile.

\begin{tabular}{lcccc}
\hline & $\begin{array}{c}(1) \\
\text { Quartile }\end{array}$ & $\begin{array}{c}(2) \\
\text { Quartile } 2\end{array}$ & $\begin{array}{c}(3) \\
\text { Quartile } 3\end{array}$ & $\begin{array}{c}(4) \\
\text { Quartile 4 }\end{array}$ \\
Eligible & $27 \%$ & $48 \%$ & $61 \%$ & $51 \%$ \\
Not Eligible & $73 \%$ & $51 \%$ & $39 \%$ & $49 \%$ \\
Of those not eligible: & & & & \\
Tenure only not met & $11 \%$ & $13 \%$ & $9 \%$ & $13 \%$ \\
Hours only not met & $2 \%$ & $6 \%$ & $4 \%$ & $7 \%$ \\
Firm size only not met & $32 \%$ & $28 \%$ & $42 \%$ & $60 \%$ \\
Tenure \& hours not met & $11 \%$ & $6 \%$ & $4 \%$ & $0 \%$ \\
Tenure \& firm size not met & $23 \%$ & $22 \%$ & $4 \%$ & $13 \%$ \\
Hours \& firm size not met & $7 \%$ & $13 \%$ & $17 \%$ & $7 \%$ \\
No criteria met & $14 \%$ & $13 \%$ & $21 \%$ & $0 \%$ \\
Overall, of those not eligible: & & & & \\
Tenure < 12 months & $43 \%$ & $28 \%$ & $15 \%$ & $13 \%$ \\
Hours < 1,250 & $25 \%$ & $20 \%$ & $18 \%$ & $7 \%$ \\
Firm size < 50 & $55 \%$ & $39 \%$ & $33 \%$ & $39 \%$ \\
\hline
\end{tabular}

* Notes: See table 2. NLSY data on births between January 1, 1986 and August 7, 1993. Excluding persons where firm size, tenure or hours worked is missing. Quartile defined by family income. 
Table 4b: Eligibility for Parental Leaves under the FMLA and Criteria for Eligibility by Family Income Quartile.

\begin{tabular}{lcccc}
\hline & $\begin{array}{c}(1) \\
\text { Quartile }\end{array}$ & $\begin{array}{c}(2) \\
\text { Quartile } 2\end{array}$ & $\begin{array}{c}(3) \\
\text { Quartile } 3\end{array}$ & $\begin{array}{c}(4) \\
\text { Quartile 4 }\end{array}$ \\
Eligible & $32 \%$ & $39 \%$ & $53 \%$ & $50 \%$ \\
Not Eligible & $68 \%$ & $61 \%$ & $47 \%$ & $50 \%$ \\
Of those not eligible: & & & & \\
Tenure only not met & $8 \%$ & $16 \%$ & $14 \%$ & $10 \%$ \\
Hours only not met & $9 \%$ & $6 \%$ & $5 \%$ & $6 \%$ \\
Firm size only not met & $43 \%$ & $48 \%$ & $51 \%$ & $53 \%$ \\
Tenure \& hours not met & $9 \%$ & $10 \%$ & $5 \%$ & $1 \%$ \\
Tenure \& firm size not met & $15 \%$ & $5 \%$ & $9 \%$ & $11 \%$ \\
Hours \& firm size not met & $8 \%$ & $7 \%$ & $5 \%$ & $14 \%$ \\
No criteria met & $8 \%$ & $7 \%$ & $9 \%$ & $4 \%$ \\
Overall, of those not eligible: & & & & \\
Tenure < 12 months & $28 \%$ & $23 \%$ & $18 \%$ & $14 \%$ \\
Hours < 1,250 & $23 \%$ & $19 \%$ & $12 \%$ & $13 \%$ \\
Firm size < 50 & $51 \%$ & $42 \%$ & $36 \%$ & $41 \%$ \\
\hline
\end{tabular}

* Notes: See table 2. NLSY data on births between August 7, 1993 and December 31, 1999.

Excluding persons where firm size, tenure or hours worked is missing. Quartile defined by family income. 
Table 4c: Eligibility for Parental Leaves under the FMLA and Criteria for Eligibility by Family Income Quartile. CPS January and March Supplements.

\begin{tabular}{lcccc}
\hline & $\begin{array}{c}(1) \\
\text { Quartile }\end{array}$ & $\begin{array}{c}(2) \\
\text { Quartile } 2\end{array}$ & $\begin{array}{c}(3) \\
\text { Quartile } 3\end{array}$ & $\begin{array}{c}(4) \\
\text { Quartile 4 }\end{array}$ \\
Eligible & $34 \%$ & $45 \%$ & $50 \%$ & $52 \%$ \\
Not Eligible & $66 \%$ & $55 \%$ & $50 \%$ & $48 \%$ \\
Of those not eligible: & & & & \\
Tenure only not met & $11 \%$ & $11 \%$ & $15 \%$ & $20 \%$ \\
Hours only not met & $32 \%$ & $27 \%$ & $25 \%$ & $20 \%$ \\
Firm size only not met & $22 \%$ & $30 \%$ & $30 \%$ & $30 \%$ \\
Tenure \& hours not met & $10 \%$ & $7 \%$ & $7 \%$ & $7 \%$ \\
Tenure \& firm size not met & $6 \%$ & $7 \%$ & $9 \%$ & $10 \%$ \\
Hours \& firm size not met & $17 \%$ & $14 \%$ & $11 \%$ & $10 \%$ \\
No criteria met & $6 \%$ & $5 \%$ & $5 \%$ & $5 \%$ \\
Overall, of those not eligible: & & & & \\
Tenure < 12 months & $61 \%$ & $52 \%$ & $47 \%$ & $40 \%$ \\
Hours < 1,250 & $32 \%$ & $30 \%$ & $35 \%$ & $41 \%$ \\
Firm size < 50 & $48 \%$ & $54 \%$ & $54 \%$ & $53 \%$ \\
\hline
\end{tabular}

* Notes: See table 2. CPS data on births in 1996, 1998, 2000, 2002 and 2004. Excluding persons where firm size, tenure or hours worked is missing. Quartile defined by family income. CPS does not split firm size at 50 employees, and hence all estimates here are based on the splits at 25 and 100 employees. Specifically, using the 25 and 100 employee splits gives the upper and lower bounds for the estimates, and the point estimate is taken as: $Y_{100}+\left(Y_{25}-Y_{100}\right) * 0.66$. 
Table 5a: Provision and Usage of Parental Leaves Before and After the State policy reforms (preFMLA) by Family Income Quartile.

\begin{tabular}{|c|c|c|c|c|}
\hline & (1) & $(2)$ & (3) & (4) \\
\hline & Quartile 1 & Quartile 2 & Quartile 3 & Quartile 4 \\
\hline & \multicolumn{4}{|c|}{ Pre-Reform All Firms } \\
\hline Employer provides paid leave & $54 \%$ & $54 \%$ & $66 \%$ & $73 \%$ \\
\hline Takes paid leave & $19 \%$ & $19 \%$ & $26 \%$ & $43 \%$ \\
\hline Takes any leave & $38 \%$ & $35 \%$ & $40 \%$ & $56 \%$ \\
\hline \multirow[t]{2}{*}{ Leave length } & 4.7 & 3.6 & 3.9 & 7.3 \\
\hline & \multicolumn{4}{|c|}{ Pre-Reform Small Firms } \\
\hline Employer provides paid leave & $40 \%$ & $37 \%$ & $51 \%$ & $64 \%$ \\
\hline Takes paid leave & $9 \%$ & $5 \%$ & $23 \%$ & $33 \%$ \\
\hline Takes any leave & $28 \%$ & $28 \%$ & $44 \%$ & $53 \%$ \\
\hline \multirow[t]{2}{*}{ Leave length } & 3.4 & 2.2 & 3.4 & 8.0 \\
\hline & \multicolumn{4}{|c|}{ Pre-Reform Large Firms } \\
\hline Employer provides paid leave & $69 \%$ & $73 \%$ & $80 \%$ & $80 \%$ \\
\hline Takes paid leave & $31 \%$ & $35 \%$ & $29 \%$ & $50 \%$ \\
\hline Takes any leave & $50 \%$ & $46 \%$ & $37 \%$ & $59 \%$ \\
\hline \multirow[t]{2}{*}{ Leave length } & 6.3 & 5.2 & 4.4 & 6.7 \\
\hline & \multicolumn{4}{|c|}{ Post-Reform } \\
\hline Employer provides paid leave & $55 \%$ & $66 \%$ & $80 \%$ & $84 \%$ \\
\hline Takes paid leave & $28 \%$ & $33 \%$ & $43 \%$ & $66 \%$ \\
\hline Takes any leave & $40 \%$ & $52 \%$ & $62 \%$ & $79 \%$ \\
\hline \multirow[t]{2}{*}{ Leave length } & 3.7 & 6.4 & 6.6 & 8.7 \\
\hline & \multicolumn{4}{|c|}{ Post-Reform Small Firms } \\
\hline Employer provides paid leave & $43 \%$ & $53 \%$ & $60 \%$ & $76 \%$ \\
\hline Takes paid leave & $27 \%$ & $20 \%$ & $24 \%$ & $48 \%$ \\
\hline Takes any leave & $43 \%$ & $44 \%$ & $56 \%$ & $64 \%$ \\
\hline \multirow[t]{2}{*}{ Leave length } & 3.5 & 6 & 4.6 & 7.1 \\
\hline & \multicolumn{4}{|c|}{ Post-Reform Large Firms } \\
\hline Employer provides paid leave & $74 \%$ & $75 \%$ & $94 \%$ & $89 \%$ \\
\hline Takes paid leave & $30 \%$ & $42 \%$ & $56 \%$ & $78 \%$ \\
\hline Takes any leave & $35 \%$ & $58 \%$ & $67 \%$ & $89 \%$ \\
\hline Leave length & 3.8 & 6.6 & 8.0 & 9.7 \\
\hline
\end{tabular}

* Notes: See table 2. NLSY data on births between January 1, 1986 and and August 6, 1993, in states that implemented a reform prior to the FMLA. Excluding persons where firm size, tenure or hours worked is missing, as well as those where no family incole is reported. Quartile defined by family income. Small firms have fewer than 50 employees, while large firms have at least 50 employees. 
Table 5b: Provision and Usage of Parental Leaves Before and After the FMLA by Family Income Quartile.

\begin{tabular}{|c|c|c|c|c|}
\hline & (1) & $(2)$ & (3) & (4) \\
\hline & Quartile 1 & Quartile 2 & Quartile 3 & Quartile 4 \\
\hline & \multicolumn{4}{|c|}{ Pre-FMLA } \\
\hline Employer provides paid leave & $55 \%$ & $64 \%$ & $65 \%$ & $75 \%$ \\
\hline Takes paid leave & $22 \%$ & $26 \%$ & $35 \%$ & $45 \%$ \\
\hline Takes any leave & $36 \%$ & $43 \%$ & $50 \%$ & $59 \%$ \\
\hline \multirow[t]{2}{*}{ Leave length } & 3.8 & 4.5 & 4.9 & 5.7 \\
\hline & \multicolumn{4}{|c|}{ Pre-Reform Small Firms } \\
\hline Employer provides paid leave & $46 \%$ & $47 \%$ & $53 \%$ & $64 \%$ \\
\hline Takes paid leave & $17 \%$ & $16 \%$ & $22 \%$ & $31 \%$ \\
\hline Takes any leave & $30 \%$ & $33 \%$ & $38 \%$ & $52 \%$ \\
\hline \multirow[t]{2}{*}{ Leave length } & 3.1 & 3.5 & 3.6 & 4.7 \\
\hline & \multicolumn{4}{|c|}{ Pre-Reform Large Firms } \\
\hline Employer provides paid leave & $69 \%$ & $79 \%$ & $78 \%$ & $84 \%$ \\
\hline Takes paid leave & $29 \%$ & $35 \%$ & $47 \%$ & $57 \%$ \\
\hline Takes any leave & $44 \%$ & $52 \%$ & $62 \%$ & $65 \%$ \\
\hline \multirow[t]{2}{*}{ Leave length } & 4.7 & 5.3 & 6.2 & 6.5 \\
\hline & \multicolumn{4}{|c|}{ Post-FMLA } \\
\hline Employer provides paid leave & $60 \%$ & $70 \%$ & $88 \%$ & $82 \%$ \\
\hline Takes paid leave & $27 \%$ & $38 \%$ & $54 \%$ & $58 \%$ \\
\hline Takes any leave & $45 \%$ & $47 \%$ & $67 \%$ & $66 \%$ \\
\hline \multirow[t]{2}{*}{ Leave length } & 3.4 & 4.6 & 7.1 & 5.8 \\
\hline & \multicolumn{4}{|c|}{ Post-Reform Small Firms } \\
\hline Employer provides paid leave & $54 \%$ & $53 \%$ & $85 \%$ & $64 \%$ \\
\hline Takes paid leave & $30 \%$ & $28 \%$ & $48 \%$ & $49 \%$ \\
\hline Takes any leave & $50 \%$ & $35 \%$ & $60 \%$ & $58 \%$ \\
\hline \multirow[t]{2}{*}{ Leave length } & 3.2 & 2.5 & 6.4 & 4.2 \\
\hline & \multicolumn{4}{|c|}{ Post-Reform Large Firms } \\
\hline Employer provides paid leave & $67 \%$ & $82 \%$ & $90 \%$ & $95 \%$ \\
\hline Takes paid leave & $24 \%$ & $45 \%$ & $59 \%$ & $64 \%$ \\
\hline Takes any leave & $39 \%$ & $55 \%$ & $71 \%$ & $73 \%$ \\
\hline Leave length & 3.7 & 6 & 7.6 & 7.1 \\
\hline
\end{tabular}

* Notes: See table 2. NLSY data on births between August 7, 1993 and December 31, 1999, in states that had not implemented a reform prior to the FMLA. Excluding persons where firm size, tenure or hours worked is missing, as well as those where no family incole is reported. Quartile defined by family income. Small firms have fewer than 50 employees, while large firms have at least 50 employees. 
Table 5c: Post-Birth Employment and Usage of Parental Leaves Before and After the FMLA by Family Income Quartile. CPS June Supplement.

\begin{tabular}{|c|c|c|c|c|}
\hline & (1) & $(2)$ & (3) & (4) \\
\hline & Quartile 1 & Quartile 2 & Quartile 3 & Quartile 4 \\
\hline & \multicolumn{4}{|c|}{ Pre-FMLA } \\
\hline Employed in June & $69 \%$ & $83 \%$ & $94 \%$ & $94 \%$ \\
\hline On parental leave & $26 \%$ & $39 \%$ & $42 \%$ & $48 \%$ \\
\hline \multirow[t]{2}{*}{ On parental leave or vacation } & $26 \%$ & $39 \%$ & $42 \%$ & $48 \%$ \\
\hline & \multicolumn{4}{|c|}{ Births in April - June, Employed in June } \\
\hline On parental leave & $38 \%$ & $47 \%$ & $45 \%$ & $52 \%$ \\
\hline \multirow[t]{2}{*}{ On parental leave or vacation } & $38 \%$ & $47 \%$ & $45 \%$ & $52 \%$ \\
\hline & \multicolumn{4}{|c|}{ Post-FMLA } \\
\hline Employed in June & $83 \%$ & $87 \%$ & $96 \%$ & $94 \%$ \\
\hline On parental leave & $38 \%$ & $44 \%$ & $59 \%$ & $61 \%$ \\
\hline \multirow[t]{2}{*}{ On parental leave or vacation } & $39 \%$ & $45 \%$ & $61 \%$ & $65 \%$ \\
\hline & \multicolumn{4}{|c|}{ Births in April - June, Employed in June } \\
\hline On parental leave & $46 \%$ & $50 \%$ & $62 \%$ & $66 \%$ \\
\hline On parental leave or vacation & $47 \%$ & $51 \%$ & $64 \%$ & $70 \%$ \\
\hline
\end{tabular}

* Notes: CPS data on births in 1990, 1002, 1994, 1995 and 1998. Sample includes women aged 20 to 40 who were working for private sector firms during the previous 12 months prior to the survey. Excluding persons where no family income is reported. Quartile defined by family income within the CPS year. 
Table 6: Eligibility Criteria and Parental Leave Taking by Family Income Quartile

\begin{tabular}{|c|c|c|c|c|c|c|}
\hline & \multicolumn{3}{|c|}{ Births during 1986-1999 } & \multicolumn{3}{|c|}{ Births after state reform or FMLA } \\
\hline & (1) & (2) & (3) & (4) & (5) & (6) \\
\hline & Meet Criteria & Meet Criteria & Any leave & Meet Criteria & Meet Criteria & Any leave \\
\hline Quartile 2 & $\begin{array}{c}0.104 * * * \\
(0.026)\end{array}$ & & & $\begin{array}{c}0.156^{* * *} \\
(0.049)\end{array}$ & & \\
\hline Quartile 3 & $\begin{array}{c}0.136 * * * \\
(0.028)\end{array}$ & & & $\begin{array}{c}0.229 * * * \\
(0.053)\end{array}$ & & \\
\hline Quartile 4 & $\begin{array}{c}0.165^{* * *} \\
(0.030)\end{array}$ & & & $\begin{array}{c}0.189 * * * \\
(0.057)\end{array}$ & & \\
\hline Ln(Family Income) & & $\begin{array}{c}-0.038 * * * \\
(0.015)\end{array}$ & $\begin{array}{c}-0.025 * \\
(0.015)\end{array}$ & & $\begin{array}{c}-0.405^{* * *} \\
(0.115)\end{array}$ & $\begin{array}{c}-0.286^{* *} \\
(0.112)\end{array}$ \\
\hline Ln(Family Income $)^{2}$ & & $\begin{array}{c}0.004^{* * *} \\
(0.001)\end{array}$ & $\begin{array}{c}0.003 * * \\
(0.001)\end{array}$ & & $\begin{array}{c}0.071 * * * \\
(0.020)\end{array}$ & $\begin{array}{c}0.049 * * \\
(0.020)\end{array}$ \\
\hline Ln(Family Income $)^{3}$ & & & & & $\begin{array}{c}-0.003^{* * *} \\
(0.001)\end{array}$ & $\begin{array}{c}-0.002 * * \\
(0.001)\end{array}$ \\
\hline Estimated effect at the: & & & & & & \\
\hline 25th centile & & 0.024 & -0.014 & & 0.052 & -0.038 \\
\hline Median & & 0.072 & 0.011 & & 0.145 & 0.007 \\
\hline 75th centile & & 0.101 & 0.026 & & 0.170 & 0.015 \\
\hline Number of Observations & 2,493 & 2,493 & 2,493 & 866 & 866 & 866 \\
\hline Adjusted $\mathrm{R}^{2}$ & 0.110 & 0.111 & 0.158 & 0.105 & 0.106 & 0.137 \\
\hline
\end{tabular}

* Notes:See table 2. All regressions include controls for race, schooling, age group, marital status, spouse's schooling, number of children ages 0-2 and 3-5, total family income, mother's hourly wage prior to birth and state unemployment rate. The regressions also include state and year of birth dummies. Robust standard errors in parentheses. 
Table 7: Parental Leave Taking and Family Income: FMLA and State Reforms

\begin{tabular}{|c|c|c|c|c|c|c|c|c|c|}
\hline & \multicolumn{6}{|c|}{ FMLA Policy Change } & \multicolumn{3}{|c|}{ State Policy Changes } \\
\hline & (1) & (2) & (3) & (4) & (5) & (6) & (7) & (8) & (9) \\
\hline & \multicolumn{3}{|c|}{ All States } & \multicolumn{3}{|c|}{ Non-Reform States } & \multicolumn{3}{|c|}{ Pre-FMLA Births } \\
\hline & Any Leave & Paid Leave & Leave Length & Any Leave & Paid Leave & Leave Length & Any Leave & Paid Leave & Leave Length \\
\hline Post-Reform & $\begin{array}{c}0.179 * * \\
(0.098)\end{array}$ & $\begin{array}{c}0.089 \\
(0.093)\end{array}$ & $\begin{array}{c}5.000 * * * \\
(1.484)\end{array}$ & $\begin{array}{c}0.146 \\
(0.122)\end{array}$ & $\begin{array}{l}-0.028 \\
(0.115)\end{array}$ & $\begin{array}{c}4.052 * * \\
(1.797)\end{array}$ & $\begin{array}{c}0.024 \\
(0.091)\end{array}$ & $\begin{array}{c}0.008 \\
(0.084)\end{array}$ & $\begin{array}{l}-0.576 \\
(1.373)\end{array}$ \\
\hline Ln(Family Income) & $\begin{array}{c}-0.232^{* * *} \\
(0.069)\end{array}$ & $\begin{array}{c}-0.209^{* *} \\
(0.065)\end{array}$ & $\begin{array}{c}-2.485^{* *} \\
(1.044)\end{array}$ & $\begin{array}{c}-0.205^{* *} \\
(0.084)\end{array}$ & $\begin{array}{c}-0.194^{* *} \\
(0.079)\end{array}$ & $\begin{array}{c}-3.154^{* * *} \\
(1.237)\end{array}$ & $\begin{array}{c}-0.048^{* * *} \\
(0.018)\end{array}$ & $\begin{array}{c}-0.053^{* * *} \\
(0.016)\end{array}$ & $\begin{array}{c}-0.639 * * \\
(0.266)\end{array}$ \\
\hline Ln(Family Income) ${ }^{<}$ & $\begin{array}{c}0.003^{* *} \\
(0.001)\end{array}$ & $\begin{array}{c}0.035^{* * *} \\
(0.011)\end{array}$ & $\begin{array}{c}0.413^{* *} \\
(0.190)\end{array}$ & $\begin{array}{r}0.035^{* *} \\
(0.015)\end{array}$ & $\begin{array}{r}0.033^{* *} \\
(0.014)\end{array}$ & $\begin{array}{c}0.558^{* *} \\
(0.221)\end{array}$ & $\begin{array}{c}0.005^{* * *} \\
(0.002)\end{array}$ & $\begin{array}{c}0.005^{* * *} \\
(0.001)\end{array}$ & $\begin{array}{r}0.057^{* *} \\
(0.024)\end{array}$ \\
\hline Ln(Family Income) $)^{3}$ & $\begin{array}{c}-0.002 * * * \\
(0.001)\end{array}$ & $\begin{array}{c}-0.001 * * * \\
(0.001)\end{array}$ & $\begin{array}{c}-0.017^{* *} \\
(0.008)\end{array}$ & $\begin{array}{c}-0.002 * * \\
(0.001)\end{array}$ & $\begin{array}{c}-0.001 * * \\
(0.000)\end{array}$ & $\begin{array}{c}-0.002^{* *} \\
(0.001)\end{array}$ & & & \\
\hline Income * Post-Reform & $\begin{array}{l}-0.005 \\
(0.005)\end{array}$ & $\begin{array}{l}-0.003 \\
(0.005)\end{array}$ & $\begin{array}{l}-0.007 \\
(0.079)\end{array}$ & $\begin{array}{l}-0.001 \\
(0.007)\end{array}$ & $\begin{array}{c}0.006 \\
(0.006)\end{array}$ & $\begin{array}{c}0.085 \\
(0.096)\end{array}$ & $\begin{array}{c}0.001 \\
(0.007)\end{array}$ & $\begin{array}{c}0.002 \\
(0.007)\end{array}$ & $\begin{array}{c}0.140 \\
(0.120)\end{array}$ \\
\hline Reform State & & & & & & & $\begin{array}{l}-0.042 \\
(0.365)\end{array}$ & $\begin{array}{c}0.094 \\
(0.337)\end{array}$ & $\begin{array}{l}-3.603 \\
(5.514)\end{array}$ \\
\hline \multicolumn{10}{|l|}{ Estimated effect at the: } \\
\hline 25th centile & -0.025 & -0.033 & -0.608 & -0.021 & -0.029 & -0.477 & -0.034 & -0.042 & -0.864 \\
\hline Median & 0.034 & 0.030 & 0.076 & 0.035 & 0.025 & 0.123 & 0.013 & 0.009 & -0.337 \\
\hline 75th centile & 0.055 & 0.054 & 0.331 & 0.054 & 0.044 & 0.254 & 0.042 & 0.040 & -0.009 \\
\hline Number of Observations & 2,493 & 2,493 & 2,493 & 1,721 & 1,721 & 1,721 & 1,866 & 1,866 & 1,866 \\
\hline Adjusted $\mathrm{R}^{2}$ & 0.161 & 0.180 & 0.108 & 0.158 & 0.177 & 0.097 & 0.162 & 0.185 & 0.093 \\
\hline F-statistic & 7.39 & 8.31 & 5.00 & 6.29 & 7.05 & 4.04 & 6.42 & 7.39 & 3.89 \\
\hline
\end{tabular}

* Notes: See table 2. All regressions include controls for race, schooling, age group, marital status, spouse's schooling, number of children ages 0-2 and 3-5, total family income, mother's hourly wage prior to birth and state unemployment rate. The regressions also include state and year of birth dummies. Robust standard errors in parentheses. 
Table 8: Parental Leave Taking: Effects of the FMLA Across Sub-Groups

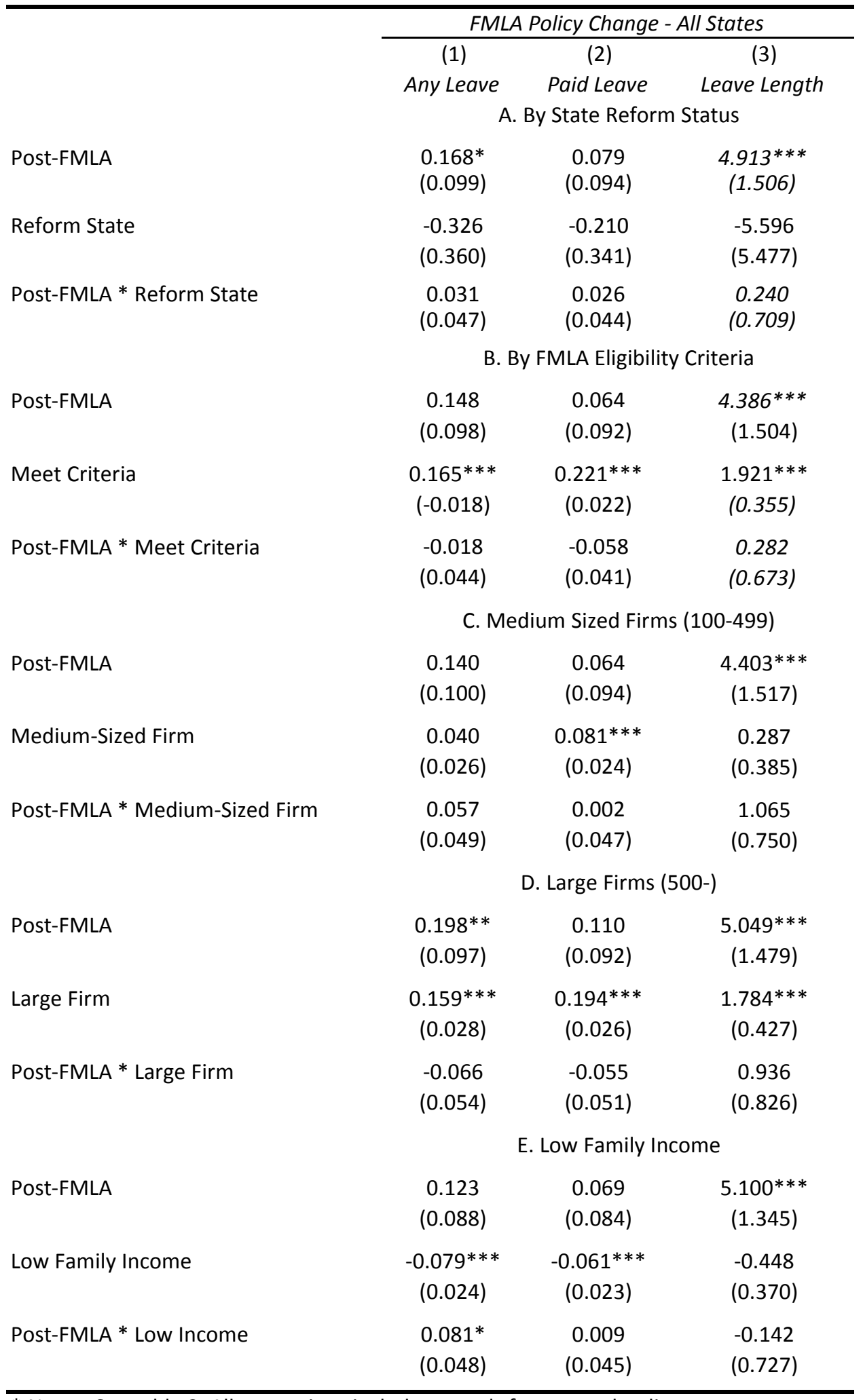

* Notes: See table 2. All regressions include controls for race, schooling, age group, marital status, spouse's schooling, number of children ages 0-2 and 3-5, total family income, mother's hourly wage prior to birth and state unemployment rate. The regressions also include state and year of birth dummies. Robust standard errors in parentheses. 
Table 10a: OLS Estimates for the Effect Taking Parental Leave on Women's Labor Market Careers: Employment, Annual Earnings, Hourly Wages and Promotions. All Families.

\begin{tabular}{|c|c|c|c|c|c|}
\hline & $\begin{array}{c}(1) \\
\operatorname{Pr}(\text { Employed) }\end{array}$ & $\begin{array}{c}(2) \\
\operatorname{Pr}(\text { Unemployed) }\end{array}$ & $\begin{array}{c}(3) \\
\log (\text { Earnings })\end{array}$ & $\begin{array}{c}(4) \\
\log (\text { Wage/Hr) }\end{array}$ & $\begin{array}{c}\text { (5) } \\
\operatorname{Pr}(\text { Promotion) }\end{array}$ \\
\hline & \multicolumn{5}{|c|}{ I. Take Any Parental Leave } \\
\hline 1 Year After Birth & $\begin{array}{c}.261^{* * *} \\
(.019)\end{array}$ & $\begin{array}{c}-0.093^{* * *} \\
(.022)\end{array}$ & $\begin{array}{c}.456 * * * \\
(.058)\end{array}$ & $\begin{array}{c}.138 * * * \\
(.027)\end{array}$ & $\begin{array}{c}.100 * * * \\
(.023)\end{array}$ \\
\hline 2 Years After Birth & $\begin{array}{c}.200 * * * \\
(.019)\end{array}$ & $\begin{array}{l}0.003 \\
(.020)\end{array}$ & $\begin{array}{c}.413 * * * \\
(.061)\end{array}$ & $\begin{array}{c}.144^{* * *} \\
(.027)\end{array}$ & $\begin{array}{l}.049 * * \\
(.024)\end{array}$ \\
\hline 3 Years After Birth & $\begin{array}{c}.191 * * * \\
(.021)\end{array}$ & $\begin{array}{l}-0.029 \\
(0.020)\end{array}$ & $\begin{array}{c}.408^{* * *} \\
(.069)\end{array}$ & $\begin{array}{c}.149 * * * \\
(.033)\end{array}$ & $\begin{array}{l}.004 \\
(.027)\end{array}$ \\
\hline 4 Years After Birth & $\begin{array}{c}.131 * * * \\
(.022)\end{array}$ & $\begin{array}{c}-0.042^{* *} \\
(0.019)\end{array}$ & $\begin{array}{c}.336 * * * \\
(.065)\end{array}$ & $\begin{array}{c}.131 * * * \\
(.031)\end{array}$ & $\begin{array}{l}-0.001 \\
(.035)\end{array}$ \\
\hline & \multicolumn{5}{|c|}{ II. Total Leave Length } \\
\hline 1 Year After Birth & $\begin{array}{c}.012^{* * *} \\
(.001)\end{array}$ & $\begin{array}{c}-0.006^{* * *} \\
(.002)\end{array}$ & $\begin{array}{c}.015^{* * *} \\
(.004)\end{array}$ & $\begin{array}{l}.004^{* *} \\
(.002)\end{array}$ & $\begin{array}{l}.003^{*} \\
(.002)\end{array}$ \\
\hline 2 Years After Birth & $\begin{array}{c}.009 * * * \\
(.001)\end{array}$ & $\begin{array}{l}-0.001 \\
(0.001)\end{array}$ & $\begin{array}{l}.009 * * \\
(.004)\end{array}$ & $\begin{array}{c}.005^{* * *} \\
(.002)\end{array}$ & $\begin{array}{c}.002 \\
(.002)\end{array}$ \\
\hline 3 Years After Birth & $\begin{array}{c}.008 * * * \\
(.001)\end{array}$ & $\begin{array}{c}-0.002 * \\
(.001)\end{array}$ & $\begin{array}{l}.008^{*} \\
(.004)\end{array}$ & $\begin{array}{c}.008 * * * \\
(.002)\end{array}$ & $\begin{array}{c}.001 \\
(.002)\end{array}$ \\
\hline 4 Years After Birth & $\begin{array}{c}.006^{* * *} \\
(.001)\end{array}$ & $\begin{array}{c}-0.003^{* *} \\
(.001)\end{array}$ & $\begin{array}{l}.009 * * \\
(.004)\end{array}$ & $\begin{array}{c}.006^{* * *} \\
(.002)\end{array}$ & $\begin{array}{l}-.001 \\
(.002)\end{array}$ \\
\hline
\end{tabular}

* Notes: See table 2. Models use data on all States during January 1986 through December 1999. All regressions include controls for race, schooling, age group, marital status, spouse's schooling, number of children ages 0-2 and 3-5, total family income (up to the third polynomial), mother's hourly wage prior to birth and state unemployment rate. The regressions also include state and year of birth dummies. Robust standard errors in parentheses. 
Table 10b: OLS Estimates for the Effect Taking Parental Leave on Women's Labor Market Careers: Employment, Annual Earnings, Hourly Wages and Promotions. Low-Income Families.

\begin{tabular}{|c|c|c|c|c|c|}
\hline & $\begin{array}{c}(1) \\
\operatorname{Pr}(\text { Employed })\end{array}$ & $\begin{array}{c}\text { (2) } \\
\operatorname{Pr} \text { (Unemployed) }\end{array}$ & $\begin{array}{c}(3) \\
\log (\text { Earnings })\end{array}$ & $\begin{array}{c}(4) \\
\text { Log(Wage/Hr) }\end{array}$ & $\begin{array}{c}\text { (5) } \\
\text { Pr(Promotion) }\end{array}$ \\
\hline & \multicolumn{5}{|c|}{ I. RHS = Take Any Parental Leave } \\
\hline 1 Year After Birth & $\begin{array}{c}0.254^{* * *} \\
(0.028)\end{array}$ & $\begin{array}{c}-0.140 * * * \\
(0.035)\end{array}$ & $\begin{array}{c}0.524^{* * *} \\
(0.098)\end{array}$ & $\begin{array}{c}0.175^{* * *} \\
(0.038)\end{array}$ & $\begin{array}{c}0.090 * * * \\
(0.033)\end{array}$ \\
\hline 2 Years After Birth & $\begin{array}{c}0.196^{* * * *} \\
(0.028)\end{array}$ & $\begin{array}{l}-0.003 \\
(0.033)\end{array}$ & $\begin{array}{c}0.433^{* * *} \\
(0.107)\end{array}$ & $\begin{array}{c}0.118^{* * * *} \\
(0.036)\end{array}$ & $\begin{array}{c}0.066^{* *} \\
(0.034)\end{array}$ \\
\hline 3 Years After Birth & $\begin{array}{c}0.200 * * * \\
(0.031)\end{array}$ & $\begin{array}{c}-0.057^{*} \\
(0.032)\end{array}$ & $\begin{array}{c}0.522 * * * \\
(0.113)\end{array}$ & $\begin{array}{c}0.191 * * * \\
(0.048)\end{array}$ & $\begin{array}{l}-0.012 \\
(0.041)\end{array}$ \\
\hline \multirow[t]{2}{*}{4 Years After Birth } & $\begin{array}{c}0.126 * * * \\
(0.032)\end{array}$ & $\begin{array}{c}-0.085^{* * *} \\
(0.031)\end{array}$ & $\begin{array}{c}0.147 \\
(0.109)\end{array}$ & $\begin{array}{c}0.115^{* * *} \\
(0.040)\end{array}$ & $\begin{array}{c}0.003 \\
(0.054)\end{array}$ \\
\hline & \multicolumn{5}{|c|}{ II. RHS = Total Leave Length } \\
\hline 1 Year After Birth & $\begin{array}{c}0.011^{* * *} \\
(0.002)\end{array}$ & $\begin{array}{c}-0.009 * * * \\
(0.002)\end{array}$ & $\begin{array}{c}0.016 * * * \\
(0.006)\end{array}$ & $\begin{array}{c}0.006 * * \\
(0.002)\end{array}$ & $\begin{array}{c}0.001 \\
(0.002)\end{array}$ \\
\hline 2 Years After Birth & $\begin{array}{c}0.010 * * * \\
(0.002)\end{array}$ & $\begin{array}{l}-0.001 \\
(0.002)\end{array}$ & $\begin{array}{c}0.006 \\
(0.007)\end{array}$ & $\begin{array}{c}0.003 \\
(0.002)\end{array}$ & $\begin{array}{l}0.005^{* *} \\
(0.002)\end{array}$ \\
\hline 3 Years After Birth & $\begin{array}{c}0.010 * * * \\
(0.002)\end{array}$ & $\begin{array}{l}-0.003 \\
(0.002)\end{array}$ & $\begin{array}{c}0.004 \\
(0.006)\end{array}$ & $\begin{array}{c}0.009 * * * \\
(0.003)\end{array}$ & $\begin{array}{l}-0.001 \\
(0.002)\end{array}$ \\
\hline 4 Years After Birth & $\begin{array}{c}0.005^{* * *} \\
(0.002)\end{array}$ & $\begin{array}{c}-0.004^{* *} \\
(0.002)\end{array}$ & $\begin{array}{l}0.003 \\
(0.007)\end{array}$ & $\begin{array}{r}0.006^{* *} \\
(0.003)\end{array}$ & $\begin{array}{l}0.001 \\
(0.004)\end{array}$ \\
\hline
\end{tabular}

* Notes: See table 2. Models use data on all States during January 1986 through December 1999. Sample includes families in the bottom $50 \%$ of the family income distribution. All regressions include controls for race, schooling, age group, marital status, spouse's schooling, number of children ages $0-2$ and 3-5, total family income (up to the third polynomial), mother's hourly wage prior to birth and state unemployment rate. The regressions also include state and year of birth dummies. Robust standard errors in parentheses. 
Table 11a: Diff-in-Diff Estimates for the Effect Taking Parental Leave on Women's Labor Market Careers: Employment, Annual Earnings, Hourly Wages and Promotions. Full Sample.

\begin{tabular}{|c|c|c|c|c|c|c|}
\hline & & $\begin{array}{c}(1) \\
\operatorname{Pr}(\text { Employed })\end{array}$ & $\begin{array}{c}\text { (2) } \\
\operatorname{Pr}(\text { Unemployed) }\end{array}$ & $\begin{array}{c}\text { (3) } \\
\log (\text { Earnings })\end{array}$ & $\begin{array}{c}(4) \\
\log (\text { Wage } / \mathrm{Hr})\end{array}$ & $\begin{array}{c}\text { (5) } \\
\operatorname{Pr} \text { (Promotion) }\end{array}$ \\
\hline & & \multicolumn{5}{|c|}{ I. Take Any Parental Leave } \\
\hline \multirow[t]{2}{*}{1 Year After Birth } & Take Any Leave & $\begin{array}{c}0.264^{* * *} \\
(0.020)\end{array}$ & $\begin{array}{c}-0.114^{* * *} \\
(0.025)\end{array}$ & $\begin{array}{c}0.491^{* * *} \\
(0.065)\end{array}$ & $\begin{array}{c}0.137^{* * *} \\
(0.029)\end{array}$ & $\begin{array}{c}0.106^{* * *} \\
(0.026)\end{array}$ \\
\hline & Leave*Post-FMLA & $\begin{array}{l}-0.025 \\
(0.050)\end{array}$ & $\begin{array}{l}0.087^{*} \\
(0.048)\end{array}$ & $\begin{array}{l}-0.193 \\
(0.137)\end{array}$ & $\begin{array}{c}0.002 \\
(0.071)\end{array}$ & $\begin{array}{l}-0.023 \\
(0.052)\end{array}$ \\
\hline \multirow[t]{2}{*}{2 Years After Birth } & Take Any Leave & $\begin{array}{c}0.203 * * * \\
(0.020)\end{array}$ & $\begin{array}{c}0.007 \\
(0.022)\end{array}$ & $\begin{array}{c}0.383 * * * \\
(0.067)\end{array}$ & $\begin{array}{c}0.136^{* * *} \\
(0.029)\end{array}$ & $\begin{array}{c}0.062 * * \\
(0.027)\end{array}$ \\
\hline & Leave*Post-FMLA & $\begin{array}{l}-0.029 \\
(0.049)\end{array}$ & $\begin{array}{l}-0.015 \\
(0.044)\end{array}$ & $\begin{array}{l}-0.143 \\
(0.139)\end{array}$ & $\begin{array}{c}0.051 \\
(0.069)\end{array}$ & $\begin{array}{l}-0.051 \\
(0.053)\end{array}$ \\
\hline \multirow[t]{2}{*}{3 Years After Birth } & Take Any Leave & $\begin{array}{c}0.194^{* * *} \\
(0.023)\end{array}$ & $\begin{array}{r}-0.042^{*} \\
(0.022)\end{array}$ & $\begin{array}{c}0.443 * * * \\
(0.077)\end{array}$ & $\begin{array}{c}0.164^{* * *} \\
(0.036)\end{array}$ & $\begin{array}{c}0.020 \\
(0.032)\end{array}$ \\
\hline & Leave*Post-FMLA & $\begin{array}{l}-0.019 \\
(0.052)\end{array}$ & $\begin{array}{c}0.050 \\
(0.044)\end{array}$ & $\begin{array}{l}-0.171 \\
(0.157)\end{array}$ & $\begin{array}{l}-0.100 \\
(0.086)\end{array}$ & $\begin{array}{l}-0.053 \\
(0.056)\end{array}$ \\
\hline \multirow[t]{3}{*}{4 Years After Birth } & Take Any Leave & $\begin{array}{c}0.130 * * * \\
(0.024)\end{array}$ & $\begin{array}{c}-0.045^{* *} \\
(0.021)\end{array}$ & $\begin{array}{c}0.296 * * * \\
(0.073)\end{array}$ & $\begin{array}{c}0.131^{* * *} \\
(0.033)\end{array}$ & $\begin{array}{c}0.013 \\
(0.045)\end{array}$ \\
\hline & Leave*Post-FMLA & $\begin{array}{c}0.003 \\
(0.053)\end{array}$ & $\begin{array}{c}0.18 \\
(0.043)\end{array}$ & $\begin{array}{l}-0.178 \\
(0.147)\end{array}$ & $\begin{array}{c}0.002 \\
(0.076)\end{array}$ & $\begin{array}{l}-0.029 \\
(0.068)\end{array}$ \\
\hline & & \multicolumn{5}{|c|}{ II. Total Leave Length } \\
\hline \multirow[t]{2}{*}{1 Year After Birth } & Take Any Leave & $\begin{array}{c}0.012 * * * \\
(0.001)\end{array}$ & $\begin{array}{c}-0.006 * * * \\
(0.002)\end{array}$ & $\begin{array}{c}0.013^{* * *} \\
(0.004)\end{array}$ & $\begin{array}{c}0.003 \\
(0.002)\end{array}$ & $\begin{array}{c}0.003 \\
(0.002)\end{array}$ \\
\hline & Leave*Post-FMLA & $\begin{array}{c}-0.002 \\
(0.004)\end{array}$ & $\begin{array}{c}0.002 \\
(0.003)\end{array}$ & $\begin{array}{c}0.004 \\
(0.008)\end{array}$ & $\begin{array}{c}0.005 \\
(0.004)\end{array}$ & $\begin{array}{c}0.001 \\
(0.003)\end{array}$ \\
\hline \multirow[t]{2}{*}{2 Years After Birth } & Take Any Leave & $\begin{array}{c}0.010^{* * *} \\
(0.001)\end{array}$ & $\begin{array}{c}-0.001 \\
(0.001)\end{array}$ & $\begin{array}{c}0.005 \\
(0.004)\end{array}$ & $\begin{array}{c}0.004 * * \\
(0.002)\end{array}$ & $\begin{array}{l}0.003 * \\
(0.002)\end{array}$ \\
\hline & Leave*Post-FMLA & $\begin{array}{l}-0.002 \\
(0.003)\end{array}$ & $\begin{array}{l}-0.001 \\
(0.002)\end{array}$ & $\begin{array}{c}0.024 * * \\
(0.010)\end{array}$ & $\begin{array}{c}0.003 \\
(0.005)\end{array}$ & $\begin{array}{l}-0.003 \\
(0.004)\end{array}$ \\
\hline \multirow[t]{2}{*}{3 Years After Birth } & Take Any Leave & $\begin{array}{c}0.009 * * * \\
(0.002)\end{array}$ & $\begin{array}{c}-0.003^{* *} \\
(0.001)\end{array}$ & $\begin{array}{c}0.005 \\
(0.005)\end{array}$ & $\begin{array}{c}0.008 * * * \\
(0.002)\end{array}$ & $\begin{array}{c}0.002 \\
(0.002)\end{array}$ \\
\hline & Leave*Post-FMLA & $\begin{array}{c}-0.006 * \\
(0.003)\end{array}$ & $\begin{array}{c}0.008 \\
(0.003)\end{array}$ & $\begin{array}{c}0.011 \\
(0.010)\end{array}$ & $\begin{array}{l}-0.001 \\
(0.005)\end{array}$ & $\begin{array}{l}-0.003 \\
(0.003)\end{array}$ \\
\hline \multirow[t]{2}{*}{4 Years After Birth } & Take Any Leave & $\begin{array}{c}0.005^{* * *} \\
(0.002)\end{array}$ & $\begin{array}{c}-0.003^{* *} \\
(0.001)\end{array}$ & $\begin{array}{c}0.007 \\
(0.005)\end{array}$ & $\begin{array}{c}0.006^{* * *} \\
(0.002)\end{array}$ & $\begin{array}{c}0.001 \\
(0.003)\end{array}$ \\
\hline & Leave*Post-FMLA & $\begin{array}{c}0.002 \\
(0.003)\end{array}$ & $\begin{array}{c}0.001 \\
(0.003)\end{array}$ & $\begin{array}{c}0.011 \\
(0.010)\end{array}$ & $\begin{array}{c}-0.001 \\
(0.005)\end{array}$ & $\begin{array}{c}-0.003 \\
(0.005)\end{array}$ \\
\hline
\end{tabular}

* Notes: Models use data on all States during January 1986 through December 1999. All regressions include controls for race, schooling, age group, marital status, spouse's schooling, number of children ages 0-2 and 3-5, total family income, mother's hourly wage prior to birth and state unemployment rate. The regressions also include state and year of birth dummies. Robust standard errors in parentheses. 
Table 11b: Diff-in-Diff Estimates for the Effect Taking Parental Leave on Women's Labor Market Careers: Employment, Annual Earnings, Hourly Wages and Promotions. Low-Income Sample.

\begin{tabular}{|c|c|c|c|c|c|c|}
\hline & & $\begin{array}{c}(1) \\
\operatorname{Pr}(\text { Employed })\end{array}$ & $\begin{array}{c}\text { (2) } \\
\operatorname{Pr}(\text { Unemployed) }\end{array}$ & $\begin{array}{c}\text { (3) } \\
\log (\text { Earnings })\end{array}$ & $\begin{array}{c}(4) \\
\log (\text { Wage } / \mathrm{Hr})\end{array}$ & $\begin{array}{c}\text { (5) } \\
\operatorname{Pr} \text { (Promotion) }\end{array}$ \\
\hline & & \multicolumn{5}{|c|}{ I. Take Any Parental Leave } \\
\hline \multirow[t]{2}{*}{1 Year After Birth } & Take Any Leave & $\begin{array}{c}0.268^{* * *} \\
(0.029)\end{array}$ & $\begin{array}{c}-0.164 * * * \\
(0.039)\end{array}$ & $\begin{array}{c}0.0583^{* * *} \\
(0.104)\end{array}$ & $\begin{array}{c}0.167^{* * *} \\
(0.041)\end{array}$ & $\begin{array}{c}0.099 * * * \\
(0.036)\end{array}$ \\
\hline & Leave*Post-FMLA & $\begin{array}{l}-0.044 \\
(0.083)\end{array}$ & $\begin{array}{c}0.117 \\
(0.084)\end{array}$ & $\begin{array}{l}-0.418^{*} \\
(0.242)\end{array}$ & $\begin{array}{c}0.050 \\
(0.112)\end{array}$ & $\begin{array}{l}-0.051 \\
(0.081)\end{array}$ \\
\hline \multirow[t]{2}{*}{2 Years After Birth } & Take Any Leave & $\begin{array}{c}0.199 * * * \\
(0.030)\end{array}$ & $\begin{array}{l}-0.009 \\
(0.036)\end{array}$ & $\begin{array}{c}0.377^{* * *} \\
(0.117)\end{array}$ & $\begin{array}{c}0.129 * * * \\
(0.039)\end{array}$ & $\begin{array}{c}0.074 * * \\
(0.037)\end{array}$ \\
\hline & Leave*Post-FMLA & $\begin{array}{l}-0.039 \\
(0.080)\end{array}$ & $\begin{array}{c}0.029 \\
(0.078)\end{array}$ & $\begin{array}{l}-0.291 \\
(0.249)\end{array}$ & $\begin{array}{l}-0.103 \\
(0.103)\end{array}$ & $\begin{array}{l}-0.038 \\
(0.080)\end{array}$ \\
\hline \multirow[t]{2}{*}{3 Years After Birth } & Take Any Leave & $\begin{array}{c}0.212 * * * \\
(0.033)\end{array}$ & $\begin{array}{c}-0.073 * * \\
(0.035)\end{array}$ & $\begin{array}{c}0.465^{* * *} \\
(0.122)\end{array}$ & $\begin{array}{c}0.214^{* * *} \\
(0.051)\end{array}$ & $\begin{array}{l}0.009 \\
(0.046)\end{array}$ \\
\hline & Leave*Post-FMLA & $\begin{array}{l}-0.091 \\
(0.086)\end{array}$ & $\begin{array}{c}0.076 \\
(0.074)\end{array}$ & $\begin{array}{l}-0.310 \\
(0.256)\end{array}$ & $\begin{array}{l}-0.200 \\
(0.136)\end{array}$ & $\begin{array}{l}-0.092 \\
(0.091)\end{array}$ \\
\hline \multirow[t]{3}{*}{4 Years After Birth } & Take Any Leave & $\begin{array}{c}0.125^{* * *} \\
(0.034)\end{array}$ & $\begin{array}{c}-0.093 * * * \\
(0.034)\end{array}$ & $\begin{array}{c}0.137 \\
(0.120)\end{array}$ & $\begin{array}{c}0.129 * * * \\
(0.043)\end{array}$ & $\begin{array}{c}0.014 \\
(0.066)\end{array}$ \\
\hline & Leave*Post-FMLA & $\begin{array}{c}0.007 \\
(0.009)\end{array}$ & $\begin{array}{c}0.045 \\
(0.074)\end{array}$ & $\begin{array}{c}0.008 \\
(0.252)\end{array}$ & $\begin{array}{l}-0.091 \\
(0.111)\end{array}$ & $\begin{array}{l}-0.036 \\
(0.109)\end{array}$ \\
\hline & & \multicolumn{5}{|c|}{ II. Total Leave Length } \\
\hline \multirow[t]{2}{*}{1 Year After Birth } & Take Any Leave & $\begin{array}{c}0.011^{* * *} \\
(0.002)\end{array}$ & $\begin{array}{c}-0.009 * * * \\
(0.003)\end{array}$ & $\begin{array}{c}0.016 * * \\
(0.007)\end{array}$ & $\begin{array}{c}0.004 \\
(0.003)\end{array}$ & $\begin{array}{c}0.002 \\
(0.002)\end{array}$ \\
\hline & Leave*Post-FMLA & $\begin{array}{l}-0.006 \\
(0.007)\end{array}$ & $\begin{array}{c}0.003 \\
(0.007)\end{array}$ & $\begin{array}{l}-0.002 \\
(0.013)\end{array}$ & $\begin{array}{l}0.011^{*} \\
(0.006)\end{array}$ & $\begin{array}{l}-0.004 \\
(0.004)\end{array}$ \\
\hline \multirow[t]{2}{*}{2 Years After Birth } & Take Any Leave & $\begin{array}{c}0.010 * * * \\
(0.002)\end{array}$ & $\begin{array}{l}-0.001 \\
(0.002)\end{array}$ & $\begin{array}{c}0.001 \\
(0.007)\end{array}$ & $\begin{array}{c}0.003 \\
(0.002)\end{array}$ & $\begin{array}{c}0.006 * * * \\
(0.002)\end{array}$ \\
\hline & Leave*Post-FMLA & $\begin{array}{l}-0.004 \\
(0.005)\end{array}$ & $\begin{array}{l}-0.001 \\
(0.005)\end{array}$ & $\begin{array}{c}0.062 * * \\
(0.024)\end{array}$ & $\begin{array}{c}0.001 \\
(0.008)\end{array}$ & $\begin{array}{l}-0.007 \\
(0.006)\end{array}$ \\
\hline \multirow[t]{2}{*}{3 Years After Birth } & Take Any Leave & $\begin{array}{c}0.011^{* * *} \\
(0.002)\end{array}$ & $\begin{array}{l}-0.003 \\
(0.002)\end{array}$ & $\begin{array}{c}0.001 \\
(0.007)\end{array}$ & $\begin{array}{c}0.009 * * * \\
(0.003)\end{array}$ & $\begin{array}{c}0.002 \\
(0.003)\end{array}$ \\
\hline & Leave*Post-FMLA & $\begin{array}{c}-0.016 * * \\
(0.007)\end{array}$ & $\begin{array}{c}0.005 \\
(0.006)\end{array}$ & $\begin{array}{c}0.016 \\
(0.015)\end{array}$ & $\begin{array}{l}-0.002 \\
(0.007)\end{array}$ & $\begin{array}{l}-0.008 \\
(0.005)\end{array}$ \\
\hline \multirow[t]{2}{*}{4 Years After Birth } & Take Any Leave & $\begin{array}{c}0.005 * * \\
(0.002)\end{array}$ & $\begin{array}{c}-0.005^{* *} \\
(0.002)\end{array}$ & $\begin{array}{c}0.002 \\
(0.007)\end{array}$ & $\begin{array}{c}0.006 * * \\
(0.003)\end{array}$ & $\begin{array}{c}0.001 \\
(0.004)\end{array}$ \\
\hline & Leave*Post-FMLA & $\begin{array}{c}-0.001 \\
(0.005)\end{array}$ & $\begin{array}{c}0.003 \\
(0.005)\end{array}$ & $\begin{array}{c}0.012 \\
(0.023)\end{array}$ & $\begin{array}{c}-0.004 \\
(0.009)\end{array}$ & $\begin{array}{c}-0.002 \\
(0.009)\end{array}$ \\
\hline
\end{tabular}

* Notes: Models use data on all States during January 1986 through December 1999. All regressions include controls for race, schooling, age group, marital status, spouse's schooling, number of children ages 0-2 and 3-5, total family income, mother's hourly wage prior to birth and state unemployment rate. The regressions also include state and year of birth dummies. Robust standard errors in parentheses. 


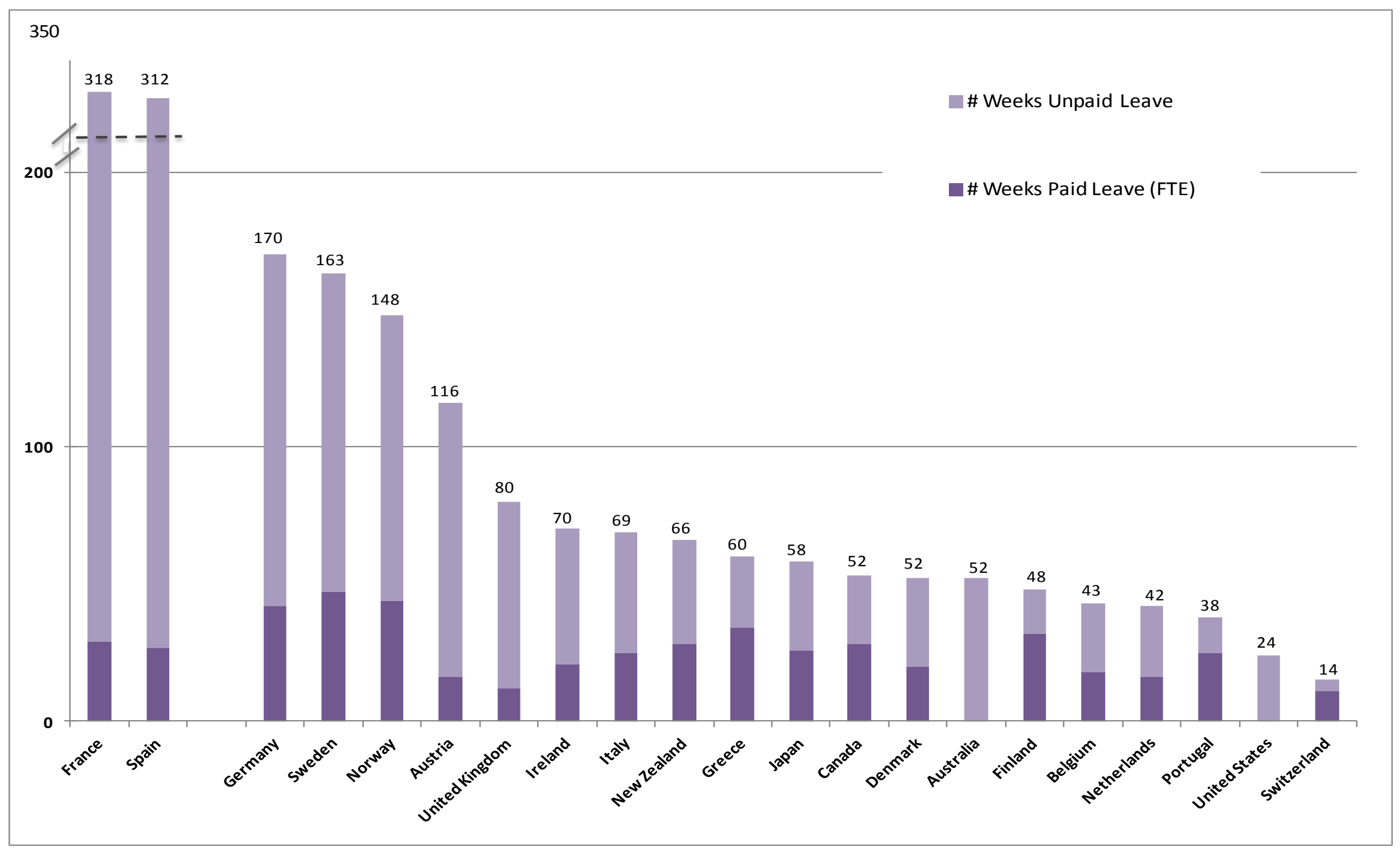

Figure 1: Parental Leave Mandates by Country: Leave Length by Type 